\title{
Does Election of an Additional Female Councilor Increase Women's Candidacy in the Future?
}

\author{
Jekaterina Kuliomina*
}

\begin{abstract}
I study the changes in female political participation that occur when an additional female candidate is elected to the local council. To address the endogeneity related to non-random election outcomes I employ a Regression Discontinuity Design. I focus on close competition for the last seat in the Czech municipal (local) elections between a male and a female candidate. I find that the election of an additional female candidate leads to fewer newly participating female candidates in the following elections. The effect is stronger in the municipalities where at least two other women were elected to the council.
\end{abstract}

JEL Classification: J16, H11

Keywords: political participation, women and politics, regression discontinuity, gender, female representation, Czech Republic

\section{Introduction}

Female political participation is a topic that draws a substantial amount of attention from international organizations and society worldwide. ${ }^{1}$ Debates about female underrepresentation have also spread to various levels of governance: from the local all the way to the national. Gender parity in political institutions is viewed as an important goal, since it is a way to account for women's preferences that may be different from men (Campbell et al 2010, Swers 2002, Wangnerud 2000). In addition, women can be better representatives than men (Anzia \& Berry 2011). Meanwhile we observe an underrepresentation of women in political institutions, not only in developing, but also in developed countries. Various ways to increase female representation, such as gender quotas (Campa 2011, Esteve-Volart \& Bagues 2012) and exposure of potential female politicians to a role model, i.e. an existing female politician (Bhalotra et al 2013, Broockman 2014, Gilardi 2015), are analysed in the literature. ${ }^{2}$ It would be useful for policy makers to know whether the process of increasing female participation only needs to be stimulated in the beginning and not for longer. At this point it remains

\footnotetext{
* CERGE-EI, a joint workplace of Charles University in Prague and the Economics Institute of the Czech Academy of Sciences, Politickych veznu 7, 11121 Prague, Czech Republic. Email: jkuliomi@cerge-ei.cz. This study was developed with institutional support RVO 67985998 from the Czech Academy of Sciences and supported by Charles University in Prague, GAUK project No.187915. I wish to thank Daniel Munich (councilor in Husinec municipality (district Praha-Vychod)), Marketa Hanakova (Mayor in Klinec municipality) and Libor Dusek for the insights about the local politics in the Czech Republic. I am grateful to Manuel Bagues, Alena Bicakova, Patrick Gaule, Jan Hanousek, Stepan Jurajda, Jan Kmenta, Nikolas Mittag and anonymous referee for their useful comments. I thank Andrea Downing for her editorial help. All remaining errors are mine.

1 Increasing the number of seats women hold in national parliaments is one of the Millenium Development Goals (United Nations). The Organization for Economic Co-operation and Development (OECD) suggests that the increase in female political participation is an important sphere to invest in.

${ }^{2}$ The topic is also extensively studied in political science. See, among others, Wolbrecht \& Campbell 2007 and Murray 2008.
} 
unclear whether a marginal increase in the number of female politicians can stimulate a spillover.

In this paper I analyse Czech local elections data and show that increasing the pool of incumbent women via a competitive election may have an opposite effect than expected, i.e. lead to fewer female candidates on slates in the next elections. Since the outcomes of the elections could potentially be endogenous to the municipality characteristics (Smith et al 2012), I employ a Regression Discontinuity Design (RDD). I compare the municipalities where the marginally elected councilor is a female who placed just ahead of a male candidate to the municipalities where the situation was the opposite.

The question of what influences female political participation has been studied in the literature from different angles. On the local level, Beaman et al (2009) and Eggers (2011) analyse the effect of electing a female mayor and De Paola et al (2010) examine how gender quota affected female representation after it was abolished. Bhalotra et al (2013) and Broockman (2014) concentrate on the state level. To the best of my knowledge, only one paper (Gilardi 2015) has so far employed the combination of the three design features that are characteristic of this paper: 1) the influence of a council seat holder rather than a mayor; 2) local political level rather than state; 3) competitive election of a female candidate rather than quota-induced. Gilardi (2015) studies both municipalities and competitive election of female council members. The setting is, however, not ordinary - Switzerland of the time when women were first allowed to participate in elections in $1969 .^{3}$ In addition, the paper is rather descriptive than causal since the identification strategy is not based on a random election of candidates. It is common in the literature to use RDD that takes into account the victory margin between the elected and unelected candidates in order to avoid endogeneity (Bhalotra et al 2013, Brollo \& Troiano 2013, Broockman 2014, Clots-Figueras 2011, Eggers 2011, Ferreira \& Gyourko 2014).

Analysing how the gender of a local council member influences other women is an important extension to the literature that already documents the influence of female mayors and state legislators. First, though less noticeable than a mayor, a council member participates in the decision-making and is among community leaders too. Second, the decision to participate in the elections on the local level is the first a potential politician takes in his/her career that can lead to becoming a mayor; the municipal level is also likely to be the first step for those who want to be involved in politics on the higher regional or state levels. Third, from the regulatory prospective, the gender of a council seat holder is relatively easy to regulate. It is, therefore, useful to study this angle to see the full picture of how female political participation is shaped.

Gender quotas introduce a large, policy-induced variation in the number of women, either on slates or among council members, and are therefore popular among researchers addressing a variety of questions (Baltrunaite et al 2014, Beaman et al 2009, Bhavnani 2009, Campa 2011, Chattopadhyay \& Duflo 2004, Chen 2010, De Paola et al 2010, Deininger et al 2015, Eggers 2011, Weeks \& Baldez 2015). Quotas, however, might also have a negative effect on attitudes of the electorate, since the latter have to choose from among a pool of candidates which is possibly not natural for them (Clayton 2015). Competitive election of women does not face this particular issue. It might be problematic due to possible unobservable women-friendliness inside a

\footnotetext{
${ }^{3}$ In the Swiss municipalities in canton of Zurich.
} 
particular municipality. Since I apply the RDD and estimate the model on a narrow margin this concern is irrelevant.

Comparing the municipalities of interest on the narrowest margin, I find that exposure of a municipality to an additional woman in local council has a negative effect on political participation of new female candidates ${ }^{4}$ in the next elections. In those municipalities we observe fewer new female candidates on slates ${ }^{5}$. The participation rate of new female candidates drops by at least 3 percentage points. ${ }^{6}$ Meanwhile, both the likelihood of an incumbent female politician participating in elections again and the likelihood of winning conditional on participation are higher than for a female candidate who ran in elections and did not get elected (in line with Trounstine 2011 and Redmond \& Regan 2015).

The negative effect on the number of new female candidates is mainly driven by the municipalities, where the number of other female candidates elected besides the marginally elected one was 2 or more. The latter finding serves as a piece of evidence that the main negative effect can be explained by the sufficiency of female representation in municipal councils.

My findings add a new insight to the existing literature. Electing a female mayor has a positive long-term effect on female political participation in India on the local level (Beaman et al 2009), as well as electing an additional female legislator on the state level (Bhalotra et al 2013). No effect was documented for France on the local level (Eggers 2011) and US on the state level (Broockman 2014). A positive effect was found in Italy (De Paola et al 2010) and in Switzerland when women were first allowed to participate in elections in 1969 (Gilardi 2015). I explain the difference between my results and those in the literature with the contrasting female political participation level that is rather high in the Czech Republic and significantly lower in India, Italy and Switzerland in the 1970s. ${ }^{7}$ I show that electing additional women might not always have a positive effect on female political participation, especially in the setting where women take a significant part in politics.

In my setting I do not find evidence for the extensively discussed "demonstration effect" (Bhalotra et al 2013, Broockman 2014, Eggers 2011, Gilardi 2015, Campbell \& Wolbrecht 2006, Wolbrecht \& Campbell 2007), whereby observing women involved in politics might inspire other women to participate in elections too. Though the possibility of a role model seems natural, to date it is only proven to affect the intentions of other women to participate in politics (Campbell \& Wolbrecht 2006, Wolbrecht \& Campbell 2007) or aspirations of adolescents (Beaman et al 2012) and, only in one case, actual participation (Gilardi 2015). With fewer female candidates on slates after a municipality was exposed to more female councilors I find no evidence in support of role model influence of elected female politicians on other women.

I also show that my results are not driven by the political affiliation of the marginally elected councilors. Multiple studies find that political parties influence policy

\footnotetext{
${ }^{4}$ New female candidates are those who did not participate in the elections in time $t-1$ when the additional female councilor was elected and do participate in the elections in time $t$.

5 A slate is a list of candidates submitted by a party to the elections committee.

${ }^{6}$ I define the participation rate of new female candidates as the number of new female candidates (3.2 on average) divided by the total number of candidates in the municipality (18.3 on average).

${ }^{7}$ In contrast to the nearly $30 \%$ of female council members in the Czech councils, in Italy approximately $7 \%$ of councilors are women, in India $-13 \%$.
} 
outcomes (Pettersson-Lidbom 2008, Joshi 2015, Migueis 2013, Freier \& Odendahl 2012). In the gender-related literature, a conclusion as to whether the partisanship of female politicians matters has not been reached. Women seem to influence women from the same party (Reingold \& Harrell 2010), and in the eyes of the electorate partisanship matters more than gender (Hayes 2011), but the political outcomes of female politicians are not affected by their partisanship (Ferreira \& Gyourko 2014). In this paper I can only respond to the question of whether it matters that the female councilor is representing a major party or a local movement. I find that representing a major party, with its clear political ideology, rather than a local movement concentrated on running the municipality efficiently, does not matter.

Since gender quotas continue to affect female political participation after they are abolished (De Paola et al 2010, Bhavnani 2009) I check whether electing an additional female councilor has a long-term effect too. I do not observe a statistically significant influence of an additionally elected female candidate on female political participation two elections ahead, possibly due to small sample size.

My findings hold for the municipalities where the competition for the last seat was narrow. Also, the municipalities where the two marginal candidates are of different gender have higher number of female candidates on slates than the municipalities where the two marginal candidates are of the same gender. The fact that the results apply to the municipalities with higher competition among women unfortunately limit the external validity of the paper.

The paper proceeds as follows. I first describe the election process in the Czech Republic in the Institutional background section. I then comment on my empirical strategy (Section 3). The data description follows (Section 4). Finally, I check whether the necessary RDD assumptions hold (Section 5) and present the results (Section 6), as well as robustness checks and minor extensions (Section 7).

\section{Institutional background}

Municipalities are the lowest level of the political system in the Czech Republic, with regional and central levels above. There are more than 6,000 municipalities in the country, where number of councilors can range from 5 to more than 50 . The majority of the municipalities (more than 4,500) are rather small - fewer than 10 councilors on the councils (Table 1). There are on average 4 slates in each municipality, which is a good approximation for the number of candidates running in elections per mandate, since most slates have as many candidates as there are mandates to be allocated (Table 2).

In my analysis I focus on small municipalities with less than 10 councilors. In these communities inhabitants are more likely to know their leaders. Also, an additional female councilor changes the gender composition of the council noticeably, unlike in the large ones. Over $70 \%$ of the participating candidates do not belong to any party and report themselves as independent candidates. This suggests that at the municipal level, the local reputation of candidates is more important than political affiliation. Changing the definition of a small municipality to less than $11,12,13$ or 14 increases the sample by $10 \%$ at most and does not influence the results. 
Table 1: Municipalities by council size

\begin{tabular}{|l|l|l|l|}
\hline & \multicolumn{2}{|l|}{ Elections year } & \\
Council size & $\mathbf{2 0 0 2}$ & $\mathbf{2 0 0 6}$ & $\mathbf{2 0 1 0}$ \\
\hline $\mathbf{5}$ & 424 & 431 & 439 \\
$\mathbf{6}$ & 50 & 48 & 31 \\
\hline $\mathbf{7}$ & 2,560 & 2,615 & 2,679 \\
$\mathbf{8}$ & 20 & 13 & 14 \\
\hline $\mathbf{9}$ & 1,506 & 1,497 & 1,457 \\
\hline $\mathbf{1 0}$ & 4 & 3 & 4 \\
\hline Total small municipalities & 4,564 & 4,607 & 4,624 \\
\hline $\mathbf{1 1}$ & 355 & 353 & 361 \\
\hline $\mathbf{1 2}$ & 2 & 3 & 4 \\
\hline $\mathbf{1 3}$ & 53 & 50 & 51 \\
\hline $\mathbf{1 4}$ & 1 & 3 & 2 \\
\hline $\mathbf{1 5}$ & 1,002 & 988 & 965 \\
\hline $\mathbf{1 7}$ and more & 342 & 346 & 346 \\
\hline Total & 6,319 & 6,350 & 6,353 \\
\hline
\end{tabular}

Municipal elections are held in all municipalities at the same time every 4 years. Recently, elections took place in 2002, 2006, 2010 and 2014. The ballots on these elections include lists of candidates (slates) representing various political parties, or slates of independent candidates who decided to create a local movement, usually with the purpose of participating in the coming elections. There tends to be more than one local movement in a given municipality and year. It is also common for two or more parties to submit a common slate. Independent candidates, as an alternative to creating a local movement, often join a particular party or local movement slate for the elections. A candidate can also participate in the elections as an individual candidate, i.e. file a slate that contains only him/her. On average, there are 2 individual candidates in a municipality (Panels A-C of the Table 2). In the municipalities that had close elections between female and male candidates for the last seat, the number of individual candidates is on average twice higher (Panels D-F of the Table 2). The municipalities where election was close are more competitive and therefore less stable, which creates demand for a higher variety among candidates and gives chance to the individual candidates.

The number of votes each voter can allocate to the candidates is equal to the number of seats to be filled in the council (n). Voters have three options: 1 ) select one particular party; 2) select $\mathrm{n}$ candidates from different slates; 3 ) select $\mathrm{m}$ candidates from different slates $(m<n)$ and a particular slate. If one party is selected, then each of the first $\mathrm{n}$ candidates from the slate gets a vote. ${ }^{8}$ If $\mathrm{m}$ candidates from different slates and a party are selected $(\mathrm{m}<\mathrm{n})$, then $\mathrm{m}$ votes are allocated to the selected candidates from different slate, and $n-m$ votes are allocated to the first $n-m$ candidates in the selected slate.

In order to participate in mandates allocation, the candidates from a given slate need to collectively receive at least $5 \%$ of all votes cast in the municipality. The threshold is adjusted for the slates that contain fewer candidates than there are mandates

${ }^{8}$ Most slates contain $\mathrm{n}$ candidates or fewer. Therefore, in case a voter selects one slate, it leads to all candidates on the slate receiving a vote. 
to be allocated. The total number of votes a given slate has collected is calculated as a simple summation of the votes received by each candidate on the slate. In case a given slate has never been selected as a whole, but one or several candidates were selected separately, the total number of votes that one or several candidates collected will count as the total number of votes the slate has collected. The mandates are allocated to the slates that passed the $5 \%$ or the adjusted $5 \%$ threshold based on the total number of votes that each slate received. The total number of votes each slate has collected is divided by 1, 2, 3 etc. The calculated number is called a Share. The Shares are ranked from highest to lowest, and the $\mathrm{n}$ highest Shares are allocated a mandate.

The mandates each slate won are then distributed to the first candidates according to the final positioning of candidates inside slate. The final ranking of candidates inside each slate, in turn, depends on their initial position on the slate, the number of votes cast for each of the candidates, as well as for the party slate that the candidate represents. Candidates with a share of votes $10 \%$ higher than the average share per candidate on the slate can move higher inside the slate (I define such candidates as jumpers). The jumpers move to the top of the slate no matter what position they were taking before, and are ranked at the top of their slate according to the number of votes they have received. Having received $10 \%$ more votes than an average candidate on the slate does not necessarily mean moving up, though. In case, for example, our jumper was 5 th on his/her slate, and four other candidates on slate collected even more votes than him/her, the jumper in question will stay on his/her initial position. The jumping candidate can even move lower in the slate in case there are 5 or more other candidates on slate that received more votes than him/her.

The candidates who did not jump, i.e. received less than $10 \%$ more votes than an average candidate on their slate, are placed below all the jumpers and are ranked based on their initial position on the slate. The number of votes they received is not taken into account when defining their final position within the slate.

On average, $26 \%$ of candidates in a municipality can be classified as jumpers, with only $40 \%$ of those having actually moved higher in the slate compared to their initial positioning. The remaining $60 \%$, even though having received $10 \%$ more votes than an average candidate on their slate, either remain on the same position, or move lower in the slate. The reason for such an outcome is that other candidates on the slate also received enough votes to be jumpers, but in addition to that they received more votes than the candidate in question, and thus moved even higher. The mean number of candidates who get elected only because they jumped and received enough votes to move higher in the slate is 1.5 per municipality (Table 2).

This mandates' allocation procedure is called d'Hondt's method and is described in more detail in Appendix A. The main feature of this method, calculating the Shares to identify who gets elected, does not allow the parties to predict precisely how many candidates from their slate will obtain a mandate in close elections, neither can they know in advance which candidate will be marginal. This method of mandates allocation allows me to observe not only the elected candidates, but also how far each unelected candidate was from being elected. Most importantly, I observe the marginally unsuccessful candidates and can calculate the winning margin of the marginally victorious candidates. The victory margin can be calculated as a difference between the Shares of the marginally successful and marginally unsuccessful candidates. For the analysis, I further express the difference between the Shares in terms of the share of 
voters who came to vote for the clearer interpretation of the results. This step is summarized in the Data description section and described in detail in Appendix A.

After the council is elected, the members of the council elect the board, the mayor and the deputy from the council members. In municipalities with fewer than 10 council members only the mayor and the deputy (in the smallest municipalities only the mayor) are elected, become full-time employees of the municipality and receive a salary. The remaining council members participate in monthly or bi-monthly meetings (and are compensated with a symbolic payment). Being elected as a mayor or deputy means quitting the current job for the term of office. ${ }^{9}$ It is important to note that if men are more likely to be the primary bread winners, their career could suffer from a 4-year break. Meanwhile, if women are more likely to be employed locally as teachers or in a similar position, a 4-year break from this type of employment is likely to be less carrier damaging. At the same time, the salary of a council leader is not likely to be significantly lower than other local salaries, but is likely to be lower than what could be earned by working in a nearby city. Serving as a council member and potentially as a mayor or a deputy is therefore likely to be more attractive to women than men. ${ }^{10}$

\section{Empirical strategy}

The mandates allocation mechanism in the Czech municipal elections allows me to apply a Regression Discontinuity design (RDD). This design has been well summarized by Imbens \& Lemieux (2008) and widely used in the recent economics literature (for example, Lee 2008, Cunat et al 2012) and also by researchers analysing elections data (Bhalotra et al 2013, Brollo \& Troiano 2013, Broockman 2014, Eggers 2011, Ferreira \& Gyourko 2014). RDD allows estimation of the local treatment effect. The identifying assumptions are not strict and can be partly tested.

The local RDD is based on estimating the local treatment effect using the observations which are close to the cut-off point of the assignment to treatment variable. The identifying assumption is that being treated or not for those observations that are around the threshold cannot be directly manipulated by the agents and is hence as good as random. The assumption can be tested by comparing the density of cases around the cut-off point. It is also assumed that the agents are not different in terms of observable and unobservable characteristics. This assumption can be tested by comparing observable characteristics of the agents that are on the different sides of the cut-off point; the observed co-variates have to be similar for these observations. The unobserved co-variates cannot be tested, but are assumed to be similar once the observed co-variates prove to be so. Controlling for the continuous assignment to the treatment variable or its polynomial is a common practice while estimating the treatment effect. This allows to account for how close the agents are to being elected, and therefore treated.

In my study I want to estimate the effect of an additional woman elected to a council, the treatment, on female political participation. The empirical strategy therefore relies on the assumption that the election of the marginal candidate is a random draw from two candidates controlling for the distance to the threshold: one who won the

\footnotetext{
9 The current employer is obliged to employ the person after the Mayor/Deputy term is over.

${ }^{10}$ In the municipalities with fewer than 10 council members there are $20 \%$ more slates headed by women. The head of the slate is likely to become a Mayor or a Deputy if the party collects a majority of votes.
} 
mandate (the so-called marginal winner) and another who follows the last-elected candidate in the final ranking (the marginal loser). Municipalities where the two marginal candidates are of different gender are therefore exposed to a different treatment in terms of the council gender composition. At the same time the source of the difference in the treatment comes from a quasi-experiment and is not driven by endogenous municipality characteristics, such as gender preferences.

The assignment to treatment variable can be constructed from the votes cast for slates and for individual candidates. As described in the Institutional framework section and in Appendix A, mandates are allocated to the slates based on the total votes cast to the slate. Within the slate the allocation of mandates is based on the initial ranking of candidates, as well as the votes cast for each candidate separately. Therefore, the victory margin is a function of the votes cast to the slate, and the final ranking of the candidates is a function of the votes cast to the candidates. Details of the victory margin calculation can be found in the Data description section and Appendix A.

To estimate the council gender composition effect on female political participation the following model is estimated. Only the municipalities where a female and a male candidates compete for the last seat are used:

Outcome $_{i}=\alpha D_{i}+\beta g\left(\right.$ VictoryMargin $\left._{i}\right)+\varepsilon_{i}$

where Outcome $_{i}$ is a municipality-specific outcome, $D_{i}$ - treatment indicator (1 if the last-elected candidate is female, 0 if male) and $g$ (VictoryMargin $\left.{ }_{i}\right)$ - quadratic function of the assignment to treatment variable, that allows for a different slope to the left and to the right sides of the cut-off.

The model is estimated using ordinary least squares, with council size and election year fixed effects, as well as robust standard errors.

The same model is used for two purposes: 1) to estimate the treatment effect on female political participation in the elections in time $t$, which follow the elections in time t-1 where the treatment happened; 2) to check the data for the co-variate balance, i.e. to verify whether RDD assumptions hold.

For the deeper analysis and robustness checks I use a modified model, that allows me to control for different indicators (Equation 2). To the Equation 1 I add the control of interest and its interaction with the main treatment indicator:

Outcome $_{i}=\alpha D_{i}+\beta g\left(\right.$ VictoryMargin $\left._{i}\right)+\gamma$ Control $_{i}+\theta$ Control $^{*} D_{i}+\varepsilon_{i}(2)$

In the Equation 2 estimation the variables of interest are the treatment indicator $D_{i}$, as well as the interaction of the treatment indicator with the control variable of interest Control $* D_{i}$.

\section{Data Description}

For this study I use the Czech municipal elections data provided by the Czech Statistical Office. The data is publicly available on the Czech Statistical Office web site ${ }^{11}$

11 The Czech Statistical Office website: https://www.czso.cz/. 
and has been studied from various angles (Jurajda \& Munich 2015, Palguta 2013, Palguta 2014, Palguta 2015). The data on the four recent elections are available and incorporated in the study: elections in 2002, 2006, 2010 and 2014.

The data-set on each of the elections presents the following candidate-level information: name, surname, age, education ${ }^{12}$, occupation ${ }^{13}$, political affiliation and initial ranking of the candidate on the slate. The elections outcomes information includes the number of votes each candidate received, the place of each candidate according to the final ranking of candidates inside the slate, the order of candidates in the mandates allocation, and an indicator of whether a candidate was elected or not. The data for separate elections has the same structure, except for a few variables which are missing in some elections and had to be recovered from other existing information.

The gender indicator was missing for three out of the four elections and had to be recovered almost manually using the names of the candidates. It was possible to determine the gender of most of the candidates from their names. In those few cases ${ }^{14}$ of names that are universal for both genders the surnames and occupation of the candidate were used to determine gender. ${ }^{15}$

In the data-sets from earlier elections, the final ranking of candidates inside each slate was missing and had to be calculated using votes cast to each candidate. Further, the procedure of allocation of mandates was replicated to find the final ranking of all candidates and calculate the victory margin among the two marginal candidates. The victory margin is expressed as a share of all voters who came to vote (see Appendix A for the calculation mechanism), such that victory margin range $[-5 ; 5]$ means that the sample for the estimation contains the municipalities where victory margin between the marginally winning and losing candidates was $5 \%$ of voters who came to vote or lower. The victory margin variable is created such that it is positive for the cases where a female candidate was marginally elected against a male candidate, and negative in the reverse cases. The cases where the victory margin is 0 are resolved using the variable indicating whether a candidate won a mandate or not, and are very rare. ${ }^{16}$

To create a pooled data-set consisting of elections in separate years I performed the following steps. First, I excluded the municipalities that had identical observations candidates with identical names, surnames and age in the same municipality. ${ }^{17}$ Next I

12 Education is not consistently reported, only $12 \%$ of all candidates in the municipalities of interest have either the pre- or post-name title present, and only $8 \%$ of the candidates do in the municipalities of interest on the narrowest margin. In the Czech Republic it is common to use education titles in most official documents. There is no reason to believe that some candidates do not report their title and it is therefore safe to assume that the lack of a title means no tertiary education.

13 Occupation is also not consistently reported. On the narrowest margin there are very few major groups of occupations, for example, retired or own business. An indicator variable of the marginal candidate being involved in one of these occupations is not significant and does not influence the main result. An indicator variable of the marginal candidate being involved in any occupation does not give an insight into results either.

${ }^{14}$ There are 6 such cases in 2006, 2 in 2010 and 8 in 2014.

15 The majority of Czech surnames have gender-specific ending; the word endings of professions are also different for men and women.

16 There are 26 such cases in 2002, 18 in 2006 and 22 in 2010.

17 There are 30 such municipalities in 2002, 14 in 2006, 10 in 2010 and 26 in 2014. 
merged separate elections data on the municipality ID, name, surname and age ${ }^{18}$ of each candidate: the municipalities treated in time $t-1$ are merged into time $t$ data-set. For example, the municipalities treated in 2002 are merged into the 2006 data-set and analogically the remaining years - 2006 into 2010 and 2010 into 2014. As a result, I end up with three pairs of elections that I pull together. I keep an indicator of each elections pairing in order to control for it in the model estimation.

Further, I drop observations that either look troublesome or inconsistent. These are the observations for the following types of municipalities: 1) those that have a missing number of mandates to be allocated ${ }^{19} ; 2$ ) those that have a number of mandates to be allocated equal to $\left.0^{20} ; 3\right)$ those that have a different number of mandates to be allocated in the two consequent elections ${ }^{21}$. The reason for the latter might be either an increase in the number of inhabitants or some possible structural change. The distribution of the excluded municipalities across the treated and the control groups does not indicate any systematic pattern and therefore does not affect the analysis.

For the purpose of my empirical strategy, I select those municipalities, or electoral districts (EDs) where the competition for the last seat in the council was between a male and a female candidate. This reduces my sample to a third of the original sample (approximately 6,000 municipalities instead of 18,000 pooled municipalities from the different years). When estimating the model, I focus on yet smaller samples where I observe the truly quasi-random variation in the treatment among the municipalities. In the sample closest to the cut-off point I am left with 935 observations (Panel F in Table 2).

Table 2: Summary statistics

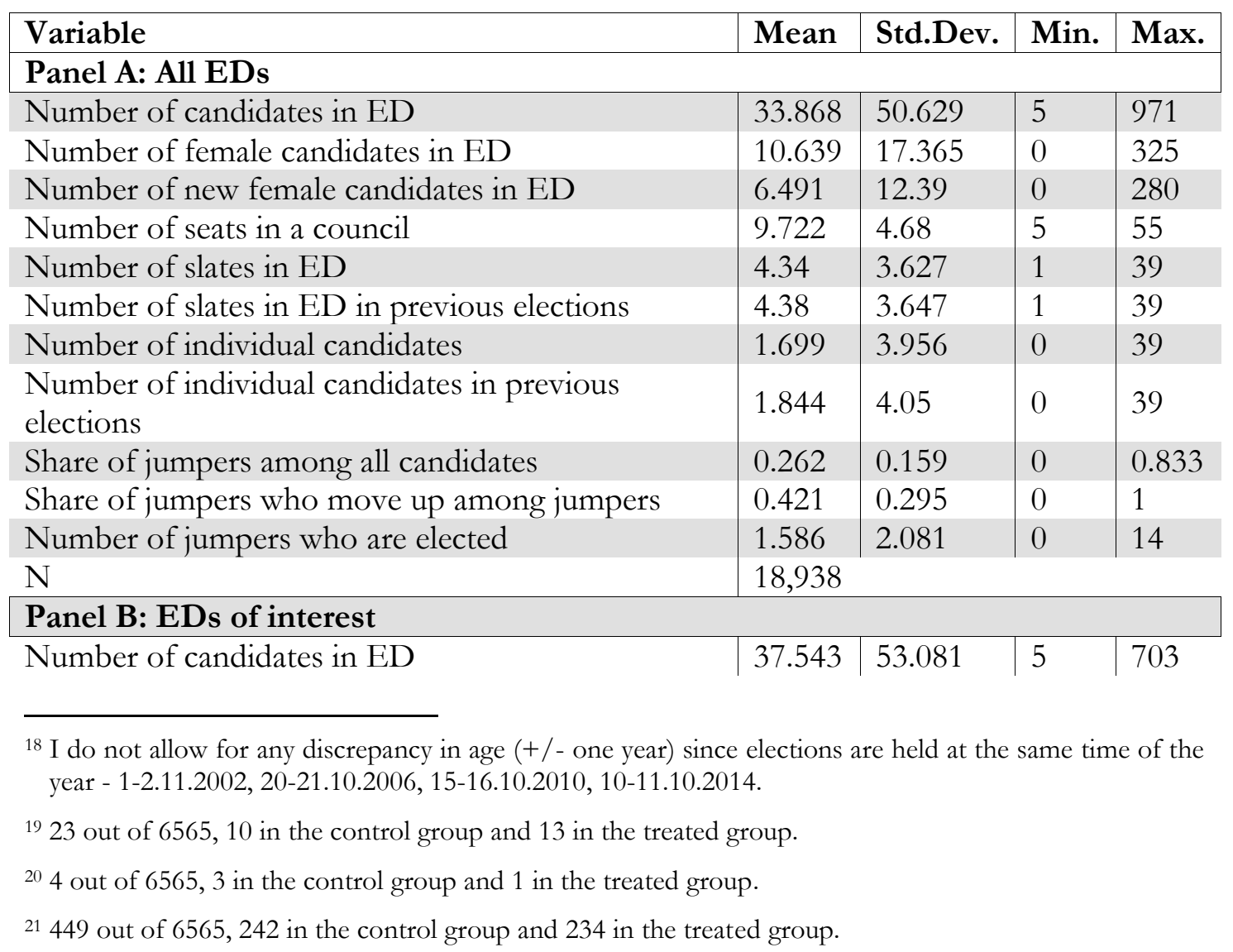




\begin{tabular}{|c|c|c|c|c|}
\hline Variable & Mean & Std.Dev. & Min. & Max. \\
\hline Number of female candidates in ED & 12.239 & 18.388 & 0 & 256 \\
\hline Number of new female candidates in ED & 7.318 & 13.016 & 0 & 202 \\
\hline Number of seats in a council & 10.022 & 4.87 & 5 & 47 \\
\hline Number of slates in ED & 4.469 & 3.507 & 1 & 28 \\
\hline Number of slates in ED in previous elections & 4.653 & 3.616 & 1 & 38 \\
\hline Number of individual candidates & 1.576 & 3.815 & 0 & 28 \\
\hline $\begin{array}{l}\text { Number of individual candidates in previous } \\
\text { elections }\end{array}$ & 1.858 & 4.101 & 0 & 38 \\
\hline Share of jumpers among all candidates & 0.286 & 0.148 & 0 & 0.833 \\
\hline Share of jumpers who move up among jumpers & 0.443 & 0.262 & 0 & 1 \\
\hline Number of jumpers who are elected & 1.828 & 2.115 & 0 & 13 \\
\hline $\mathbf{N}$ & \multicolumn{4}{|l|}{6,088} \\
\hline \multicolumn{5}{|l|}{ Panel C: Small EDs of interest } \\
\hline Number of candidates in ED & 17.351 & 11.118 & 5 & 81 \\
\hline Number of female candidates in ED & 5.612 & 4.349 & 0 & 35 \\
\hline Number of new female candidates in ED & 3.198 & 3.243 & 0 & 25 \\
\hline Number of seats in a Council & 7.474 & 1.2 & 5 & 9 \\
\hline Number of slates in ED & 4.086 & 3.59 & 1 & 24 \\
\hline Number of slates in ED in previous elections & 4.4 & 3.772 & 1 & 25 \\
\hline Number of individual candidates & 2.106 & 4.211 & 0 & 24 \\
\hline $\begin{array}{l}\text { Number of individual candidates in previous } \\
\text { elections }\end{array}$ & 2.444 & 4.451 & 0 & 25 \\
\hline Share of jumpers among all candidates & 0.286 & 0.171 & 0 & 0.833 \\
\hline Share of jumpers who move up among jumpers & 0.418 & 0.292 & 0 & 1 \\
\hline Number of jumpers who are elected & 0.968 & 1.2 & 0 & 7 \\
\hline $\mathbf{N}$ & \multicolumn{4}{|c|}{4,256} \\
\hline \multicolumn{5}{|c|}{ Panel D: Small EDs of interest, mandates $<10$, victory margin $[-5 ; 5]$} \\
\hline Number of candidates in ED & 19.024 & 12.166 & 5 & 81 \\
\hline Number of female candidates in ED & 6.084 & 4.748 & 0 & 35 \\
\hline Number of new female candidates in ED & 3.465 & 3.474 & 0 & 25 \\
\hline Number of seats in a Council & 7.689 & 1.177 & 5 & 9 \\
\hline Number of slates in ED & 5.213 & 4.021 & 1 & 24 \\
\hline Number of slates in ED in previous elections & 6.172 & 4.207 & 2 & 25 \\
\hline Number of individual candidates & 3.181 & 4.956 & 0 & 24 \\
\hline $\begin{array}{l}\text { Number of individual candidates in previous } \\
\text { elections }\end{array}$ & 4.162 & 5.36 & 0 & 25 \\
\hline Share of jumpers among all candidates & 0.224 & 0.173 & 0 & 0.833 \\
\hline Share of jumpers who move up among jumpers & 0.335 & 0.295 & 0 & 1 \\
\hline $\mathbf{N}$ & \multicolumn{4}{|c|}{2,314} \\
\hline \multicolumn{5}{|c|}{ Panel E: Small EDs of interest, mandates $<10$, victory margin $[-2 ; 2]$} \\
\hline Number of candidates in ED & 18.3 & 11.88 & 5 & 81 \\
\hline Number of female candidates in ED & 5.814 & 4.62 & 0 & 35 \\
\hline Number of new female candidates in ED & 3.226 & 3.282 & 0 & 25 \\
\hline Number of seats in a Council & 7.651 & 1.155 & 5 & 9 \\
\hline Number of slates in ED & 5.923 & 4.359 & 1 & 24 \\
\hline Number of slates in ED in previous elections & 7.246 & 4.458 & 2 & 25 \\
\hline Number of individual candidates & 4.089 & 5.408 & 0 & 24 \\
\hline
\end{tabular}




\begin{tabular}{|l|l|l|l|l|}
\hline Variable & Mean & Std.Dev. & Min. & Max. \\
\hline $\begin{array}{l}\text { Number of individual candidates in previous } \\
\text { elections }\end{array}$ & 5.433 & 5.754 & 0 & 25 \\
\hline Share of jumpers among all candidates & 0.191 & 0.175 & 0 & 0.833 \\
\hline Share of jumpers who move up among jumpers & 0.287 & 0.296 & 0 & 1 \\
\hline Number of jumpers who are elected & 0.919 & 1.257 & 0 & 7 \\
\hline N & $\mathbf{1 , 4 8 9}$ & \multicolumn{1}{|l|}{} \\
\hline Panel F: Small EDs of interest, mandates<10, victory margin [-1;1] & 18.037 & 11.874 & 5 & 81 \\
\hline Number of candidates in ED & 5.741 & 4.525 & 0 & 35 \\
\hline Number of female candidates in ED & 3.17 & 3.241 & 0 & 23 \\
\hline Number of new female candidates in ED & 7.649 & 1.124 & 5 & 9 \\
\hline Number of seats in a Council & 6.334 & 4.499 & 1 & 24 \\
\hline Number of slates in ED & 7.964 & 4.529 & 2 & 25 \\
\hline Number of slates in ED in previous elections & 4.589 & 5.587 & 0 & 24 \\
\hline Number of individual candidates & 6.304 & 5.851 & 0 & 25 \\
\hline $\begin{array}{l}\text { Number of individual candidates in previous } \\
\text { elections }\end{array}$ & 0.169 & 0.17 & 0 & 0.833 \\
\hline Share of jumpers among all candidates & 0.258 & 0.292 & 0 & 1 \\
\hline Share of jumpers who move up among jumpers & 0.814 & 1.219 & 0 & 7 \\
\hline Number of jumpers who are elected & $\mathbf{9 3 5}$ & & & \\
\hline N &
\end{tabular}

The small municipalities in the sample of greatest interest (Panels D-F in Table 2) are different from the larger ones (Panels A and B). On average, they are 30\% smaller in terms of council size (number of seats to be allocated) and twice smaller in terms of the number of candidates who run in the elections. At the same time they are not very different in the proportion of women in the pool of all candidates (around 30\% in all the sample specifications). The average number of slates - a political competition indicator, is similar across municipalities as well if we exclude the individual candidates. There are more individual candidate in the municipalities that had close elections.

The need to limit the sample to municipalities where the competition for the last seat was between two candidates of different gender unfortunately leaves me with a non-representative sample. In the municipalities where the competition for the last seat was between two candidates of the same gender (usually between two male candidates) there are fewer female candidates to vote for, they are placed slightly worse and therefore receive fewer votes (Table B.1). The number of elected female candidates, excluding the marginally elected female candidate, is however very similar even on the narrowest margin. The full summary statistics tables for the excluded municipalities are in Appendix B.

Table B.5 presents the evolution of female political participation over the years studied in all municipalities, and in small municipalities respectively. The number and share of both participating and elected female candidates in the pool of candidates increased over the years, and their positioning on slates improved too. This pattern could be of concern if I had found a positive effect of the treatment. In that case one could argue that the finding is simply the result of the overall trend. As will be presented below, the estimated treatment effect is negative and the overall trend towards higher female political participation in the local elections cannot be causing it. 


\section{RDD assumptions: co-variate balance check}

Before discussing the results, I present the RDD assumptions tests. First, the treated and the control municipalities are not different in the number of inhabitants, number of children born per year (Panel A of Table B.6), neither are they systematically distinct in the local budget income and spending per inhabitant ${ }^{22}$ on the narrowest margin around the threshold (column 5 in Panel B of the Table B.6). On wider samples (columns 1-4 in Panel B of the Table B.6) several types of spending turned out to be higher or lower in the treated municipalities, but are not systematic. The electorate in the treated municipalities does not have different preferences towards major parties ${ }^{23}$ than that in the control municipalities (Panel C of the Table B.6).

The median age of all candidates, all female candidates, elected candidates and elected female candidates is not different for the two groups of the municipalities on the narrowest margins ${ }^{24}$ (columns 3-5 in Panel D of the Table B.6). In the whole sample elected women tend to be 1.5 years older in the treated municipalities than in control ones (columns 1-2 in Panel D of the Table B.6). Although the point estimate is statistically significant, it is not so quantitatively. The education level of all candidates, female candidates, elected candidates and elected female candidates is also not different ${ }^{24}$ on the narrowest margin (columns 3-5 in Panel E of the Table B.6). There are statistically but not quantitatively more educated candidates among elected in the treated municipalities than in the control ones.

In the elections of treatment (in time t-1) the treated and the control municipalities had a similar number of the participating female candidates in the pool of all candidates, as well as the number of elected female candidates, if I exclude those who were elected marginally (Panel F of the Table B.6). Again, there is a small statistical difference in the number of female candidates and the share of votes they receive $e^{25}$ if we look at the whole sample (column 1 in Panel F of the Table B.6).

The marginal winners and losers seem to be representing the slates of the same length on average and are not more likely to be on the major party's slate ${ }^{23}$ (Panel G of the Table B.6). The marginal candidates are not different in their age or education level. The slates the marginally victorious female and male candidates represent have, on average, the same number of other candidates elected, as well as the same number of female candidates elected and the median position women occupy on the slates. As before, I observe some difference between the treated and control municipalities in the specifications where I use all sample. The difference seems to be present in those specifications where I expect selection to take place. Most importantly, the last specification, with the narrowest victory margin, shows that the treated and the control municipalities are not significantly different from each other in the placement of female

22 The outcome variables here are two-year averages: the year of the elections and the previous year.

${ }_{23}$ Major parties include KDU-CSL, SZ, CSSD, KSCM, ODS and TOP09. These are the parties that in each of the four municipal elections had more than 1,000 candidates across municipalities. CSSD, ODS, KDU-CSL and KSCM are also stably present in the Czech Parliament.

24 I exclude the two marginal candidates. In the case of elected candidates, I exclude the marginally elected candidate.

25 Number of votes that were cast to all female candidates over total number of votes cast to all the candidates in the municipality. 
candidates and the share of votes those candidates receive, as well as the number of participating and elected women.

There is only one interesting observation to make. The slates that the marginally winning women represent have a higher share of women than the slates that are represented by the marginally winning male candidates. Meanwhile, the same is true for the share of women on the slates of the marginally losing candidates. There seem to be slates that have high share of women. This does not however pose a threat to identification. The opposite case, where the marginally winning male candidates represent slates with more women, would be problematic. Then one could claim that though a man is elected, he is likely to be supporting female issues, as his party is. In my case it is not clear and rather unlikely that the women from the women-friendly slates are different in one way or another from the women that represent other slates.

I also present co-variate balance check for the large municipalities in the Table B.7. Most co-variates are similar for the treated and control municipalities. Interestingly, the number of female candidates in the elections of treatment is higher on the second to narrowest margin (column 4 in Panel F of the table Table B.7), as well as the share of female candidates and the share of votes cast to women on the margin [-5;5] (column 3 in Panel F of the table Table B.7). They are not systematically different. The one systematic difference is the better positioning of women on the marginal winners slate (Panel G of the table Table B.7), which gives a reason to think that the marginal winners' slates could also be more pro-women than other slates. Also, in the large municipalities, it is less so the case that women tend to be concentrated in particular slates (Panel G of the table Table B.7), as it was the case in the small municipalities (Panel G of the table Table B.6).

Figure 1 shows the density of cases around the cut-off point and presents evidence consistent with no manipulation happening around the cut-off. The distribution resembles a normal distribution with no clear jump in the number of observations from any of the two threshold sides.

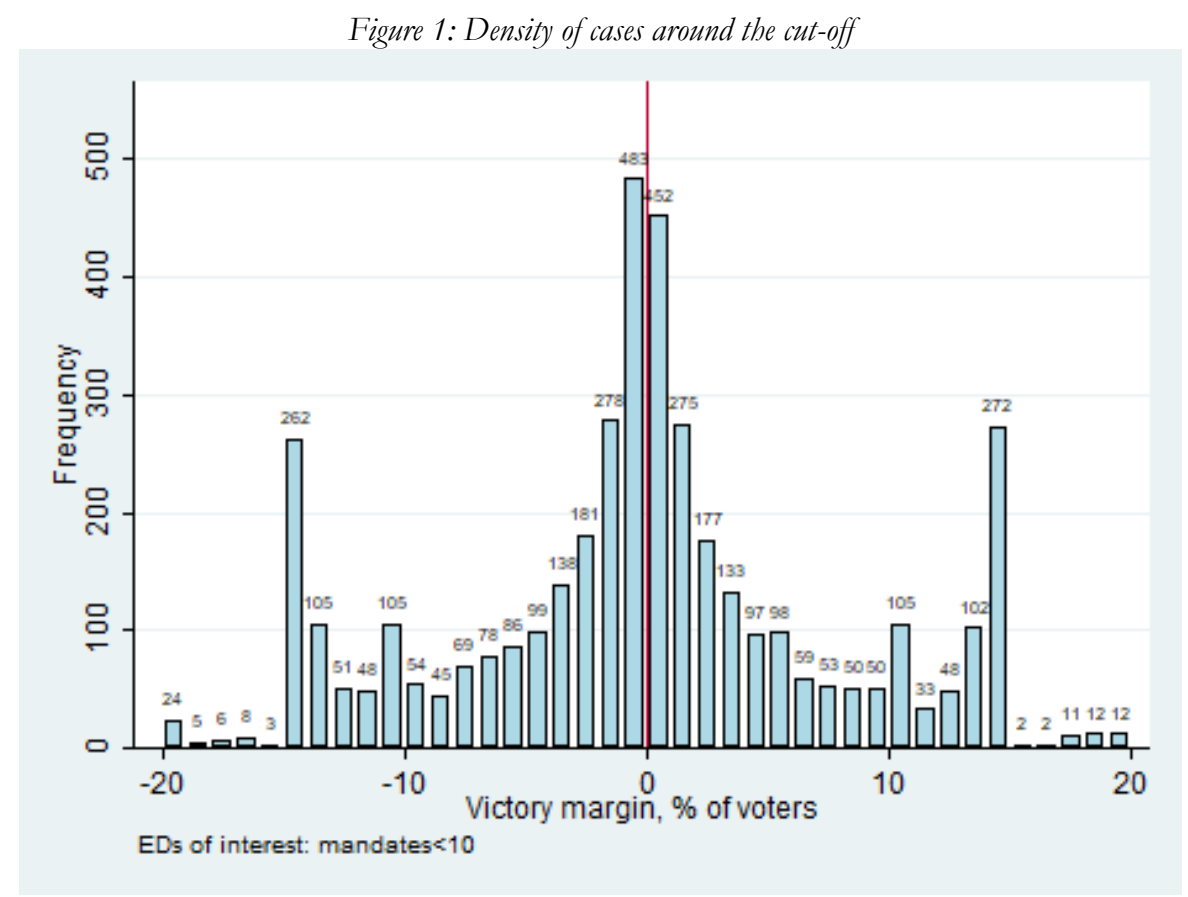




\section{Main results}

Table 3 presents the main results of the paper. The specifications of interest are the last three columns (columns 3-5 of the Table 3), where I focus on small municipalities and narrow victory margins. Electing an additional female councilor did not affect the pool of total female candidates consistently (Panels A and B of the Table $3)^{26}$, as the effect is statistically significant on the narrowest margin only if we look at all women (column 5), and not on all narrow margins if we exclude the marginally elected woman from the sample of all women (columns 3 and 5). The number of newly participating candidates has been affected more consistently: estimation on the three chosen margins shows both statistically and quantitatively significant results (Panel E of the Table 3). The effect is significant for the margins up to $[-8 ; 8]$ with the exception of the margin [-3;3] (Figure 3). The negative sign of the estimated coefficient means that on average, having a female candidate elected in the elections in time $t-1$ results in at least 0.6 fewer new female candidates in the next elections in time $t$. The newly participating female candidates are those who did not participate in the elections in time $t-1$ when the treatment happened but participate in the following elections in time $t$. With a mean number of 3.2 newly participating female candidates in the sample municipalities for the specification of interest, the treatment effect results in at least 0.6 fewer new female candidates. This drop in the number of new female candidates means that the participation rate of new female candidates is at least 3 percentage points, or $18 \%$, lower in the municipalities that were exposed to more female councilors. The corresponding graphs are presented in the Figure 2. Although the data points are visually dispersed, quadratic fit (on the graph), as well as linear and fractional polynomial fits $^{27}$ show a jump down around the cutoff.

In large municipalities the results are different and are presented in the Table B.8 in Appendix B. The effect goes the opposite direction, but is not statistically significant (Panels A, B and E). The likelihood to participate in the next elections for the marginally elected women compared to the not elected is positive (Panel C), like in small municipalities (Panel C of the Table 3), but twice lower. Interestingly, the probability to win again conditional on participation does not depend on winning in the previous elections (Panel D). In small municipalities the winning probability given participation is higher for the incumbents (Panel D of the Table 3). Therefore, in small councils, unlike in the large ones, the marginally elected candidates do become a part of the council, are noticed, and are likely to get involved with the local politics. This incumbency effect has been well documented in the literature (Trounstine 2011, Redmond \& Regan 2015 among others). This observation is intuitive and supports the earlier claim that in the large councils a marginally elected candidate is less noticeable than in the small councils.

Since the RDD estimates the local treatment effect rather than the average treatment effect, the results apply to a particular category of municipalities. Compared to the municipalities where the two marginal candidates are of the same gender (Table B.1 in the Appendix B), the municipalities with marginal candidates of opposite gender have relatively more women among candidates. Those women are not better placed and

\footnotetext{
26 I also tried as outcomes the number of female candidates who participated again, the median position of all female candidates and new female candidates on slates. They did not appear to be influenced by the treatment.

27 Available from author upon request.
} 
the number of elected women is not different either. The difference in the two types of municipalities is therefore in the level of female political activity. My results apply to the municipalities that have higher competition among women: there are more female candidates running for the council seat.

Table 3: Main results

\begin{tabular}{|c|c|c|c|c|c|}
\hline \multicolumn{6}{|c|}{ Model specifications } \\
\hline Observations & 6,088 & 4,256 & 2,314 & 1,489 & 935 \\
\hline Sample & ALL & $\begin{array}{l}\text { mandates } \\
<10\end{array}$ & $\begin{array}{l}\text { mandates } \\
<10\end{array}$ & $\begin{array}{l}\text { mandates } \\
<10\end{array}$ & $\begin{array}{l}\text { mandates } \\
<10\end{array}$ \\
\hline $\begin{array}{l}\text { Victory } \\
\text { margin }\end{array}$ & ALL & ALL & {$[-5 ; 5]$} & {$[-2 ; 2]$} & {$[-1 ; 1]$} \\
\hline \multicolumn{6}{|c|}{$\begin{array}{l}\text { Panel A } \\
\text { Number of female candidates }\end{array}$} \\
\hline Additional & 0.622 & 0.690 & -0.559 & -0.630 & $-1.116^{*}$ \\
\hline woman & $(0.407)$ & $(0.526)$ & $(0.391)$ & $(0.529)$ & $(0.654)$ \\
\hline Adj. R-sq & 0.827 & 0.821 & 0.131 & 0.131 & 0.118 \\
\hline \multicolumn{6}{|c|}{$\begin{array}{l}\text { Panel B } \\
\text { Number of female candidates, excluding the marginally winning or losing female } \\
\text { candidates }\end{array}$} \\
\hline Additional & 0.471 & 0.167 & $-0.809^{* *}$ & -0.803 & $-1.349^{* *}$ \\
\hline woman & $(0.406)$ & $(0.525)$ & $(0.386)$ & $(0.523)$ & $(0.645)$ \\
\hline Adj. R-sq & 0.827 & 0.821 & 0.132 & 0.133 & 0.124 \\
\hline \multicolumn{6}{|c|}{$\begin{array}{l}\text { Panel C } \\
\text { Participation probability: marginal female winner vs loser }\end{array}$} \\
\hline Additional & $0.151^{* * *}$ & $0.218^{* * *}$ & $0.249^{* * *}$ & $0.173^{* * *}$ & $0.232^{* * *}$ \\
\hline woman & $(0.021)$ & $(0.028)$ & $(0.045)$ & $(0.064)$ & $(0.084)$ \\
\hline Adj. R-sq & 0.047 & 0.047 & 0.042 & 0.051 & 0.044 \\
\hline \multicolumn{6}{|c|}{$\begin{array}{l}\text { Panel D } \\
\text { Probability to win again conditional on participating again: marginal female winner vs } \\
\text { loser }\end{array}$} \\
\hline Observations & 3,172 & 2,065 & 1,107 & 718 & 448 \\
\hline Additional & $0.149^{* * *}$ & $0.168^{* * *}$ & $0.239^{* * *}$ & $0.254^{* * *}$ & $0.231^{*}$ \\
\hline woman & $(0.030)$ & (0.041) & (0.068) & $(0.097)$ & $(0.128)$ \\
\hline Adj. R-sq & 0.048 & 0.037 & 0.020 & 0.027 & 0.032 \\
\hline \multicolumn{6}{|c|}{$\begin{array}{l}\text { Panel E } \\
\text { Number of newly participating female candidates }\end{array}$} \\
\hline Additional & 0.200 & -0.085 & $-0.577^{* *}$ & $-0.635^{+}$ & $-1.307^{* * *}$ \\
\hline woman & $(0.307)$ & $(0.394)$ & $(0.286)$ & $(0.387)$ & $(0.470)$ \\
\hline Adj. R-sq & 0.803 & 0.792 & 0.093 & 0.086 & 0.088 \\
\hline
\end{tabular}


Figure 2: Number of newly participating female candidates
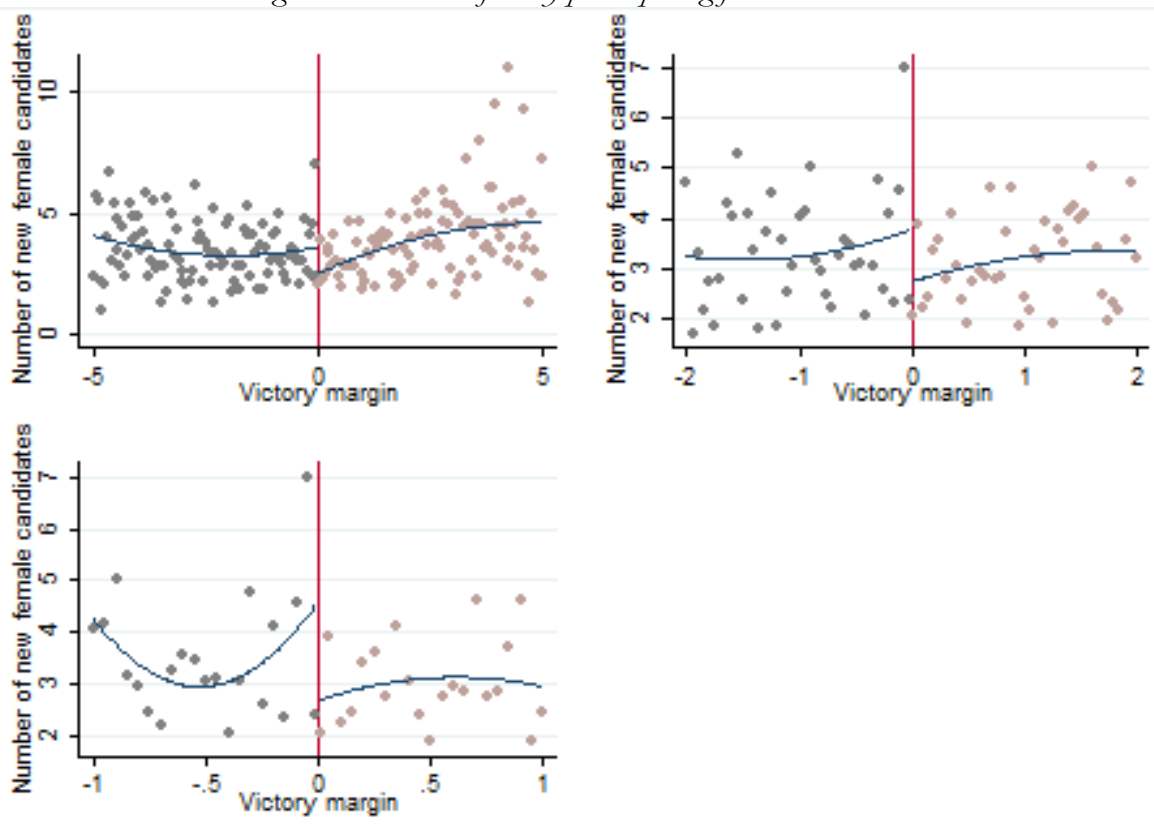

mandates $<10$

Figure 3: Main results: coefficients by victory margin

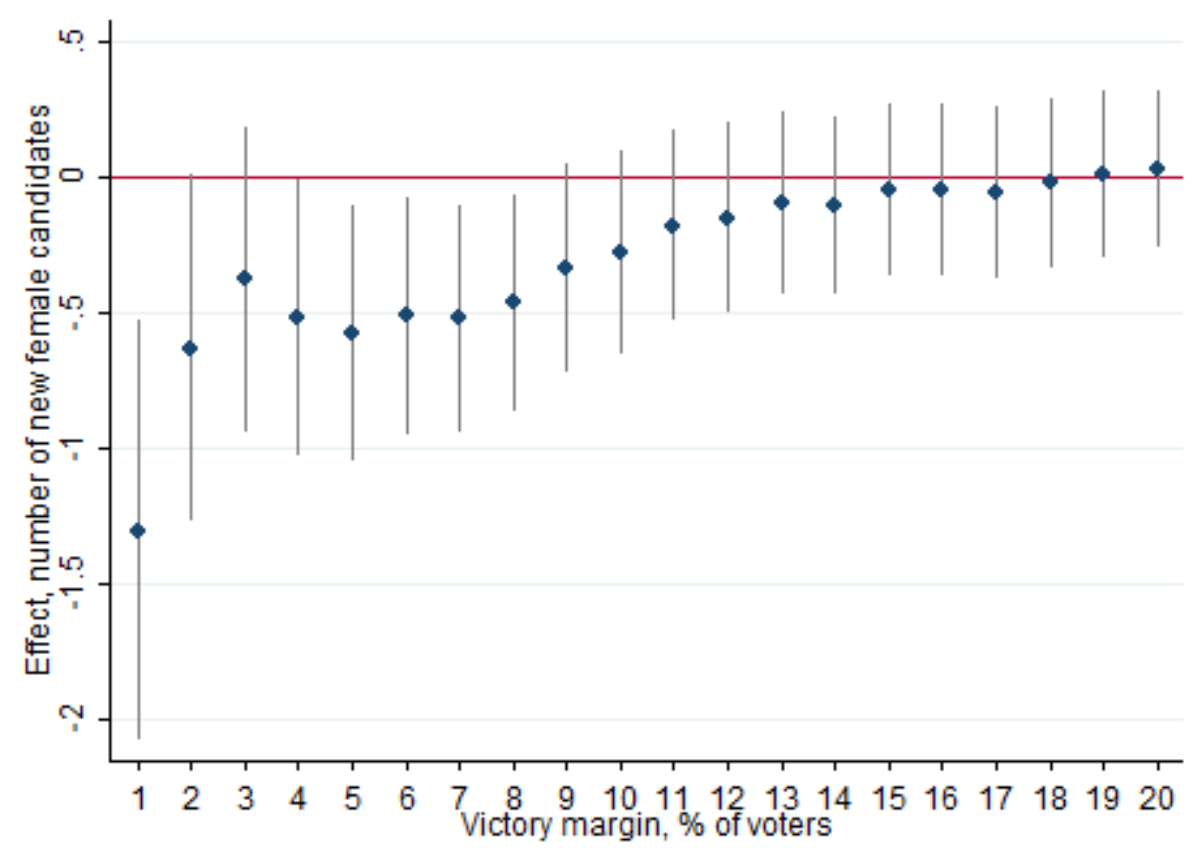

Note: Each coefficient comes from a separate regression as in the Table 3.

My findings differ from the evidence documented in the literature to date. They are likely to differ from the evidence of the positive influence of electing women in India because India is less advanced in terms of female political participation. There, 
women's share in parliament is not higher than $13 \%{ }^{28}$ (after elections in 2014) and labor force participation did not reach $30 \%$ in the years before $2014^{29}$. According to the European Commission's report on women and men in leadership positions in the European Union, in 2011 the Czech Republic was close to, yet below the European average of female participation in local politics ( $27 \%$ vs $32 \%$ on average in the EU - see Figure 4). At the same time the full-time employment rate for women reaches $60 \%$ in 2014 - one of the highest in Eupore. ${ }^{30}$ The evidence suggests that the Czech Republic is rather advanced in terms of both female political participation and female economic involvement.

Figure 4: Female political participation in local (2011) and regional (2012) levels in the Czech Republic and other EU27 countries

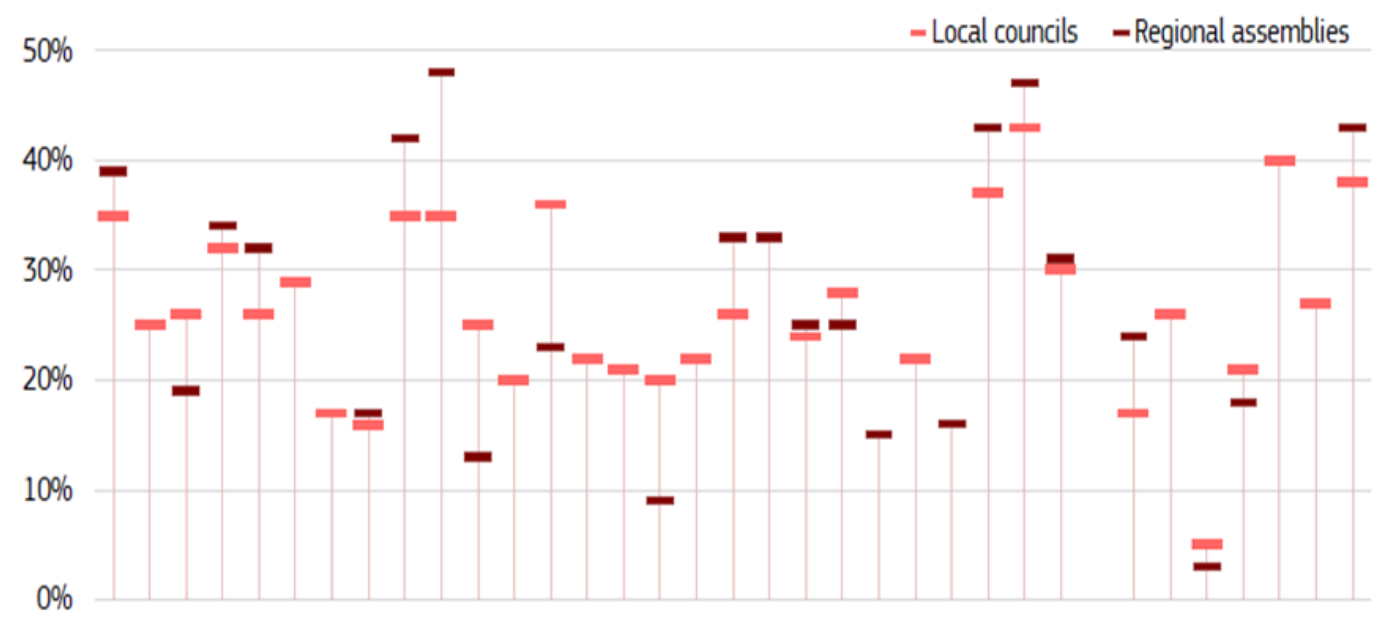

BE BG CZ DKDE EE IE EL ES FR IT CY LV LT LUHUMT NL AT PL PT RO SI SK FI SE UK HRMK TR RS IS LI NO

Source: European Commission - Women and men in leadership positions in the European Union, 2013.

Note: EU averages are $32 \%$ (local) and $27 \%$ (regional).

The difference between my findings and the positive effect documented in Italy (De Paola et al 2010) and Switzerland can also be explained with the similar reasoning. The results for Switzerland hold only shortly after the introduction of women into politics (Gilardi 2015). In Italy before the quota was introduced women used to occupy approximately $7 \%$ of local council seats (De Paola et al 2010). As summarized in the Table B.5 women are holding nearly 30\% of seats in the Czech local councils. The Czech Republic is therefore more advanced in female political participation than Italy in the 1990s and early 2000s and than Switzerland in the 1970s.

Though the direct negative effect of the female incumbents' presence on other women's political participation has not been documented to date, several studies demonstrate that having a female representative can cause either no or a negative effect on other women's interest in politics. The experimental evidence provided by Wolak (2015) shows that women are not more willing to vote when they see more women on

\footnotetext{
${ }^{28}$ Source: Inter-Parliamentary Union: http://www.ipu.org/wmn-e/classif.htm.

${ }^{29}$ Source: The World Bank: http://databank.worldbank.org/data/.

${ }^{30}$ Source: European Union Labour Force Survey,

http:/ / ec.europa.eu/eurostat/web/microdata/european-union-labour-force-survey.
} 
ballots. Clayton (2015) finds that in the municipalities that had mandates reserved for female politicians in Lesotho, women tend to be less interested in politics. In the Czech Republic, the negative influence seems to extend to decisions of potential female politicians.

While rejecting the role model type of influence of female politicians on other women in Czech municipalities, my results raise further questions regarding the mechanism behind these effects. First, what is the reason for the negative effect. Second, which side the decision comes from - the demand or the supply. With the data I have I am not able to evaluate whether these are the potential female candidates who choose not to participate in the elections, or whether these are the parties who decide not to include female candidates on slates. As for the reason for the negative effect, one could think of several explanations. The marginally elected women could have performed poorly as councilors and left the community less willing to see more women on council. Alternatively, the marginally elected women could have performed well and are expected to be elected again and cover the needed female representation in the council. With the analysis below I show that the reason for the negative effect is indeed the sufficient representation of women. In a separate analysis I have established that the result is not solely driven by those women who were elected again, i.e. were fairly successful. ${ }^{31}$ Neither is the effect stronger in the municipalities, where the marginally elected women were not elected in the next elections. I conclude that the success of the marginally elected female councilors is not likely to play a role.

To show that the sufficient representation is the likely explanation of the main result of the paper, I test whether the negative effect on the new female candidates is related to how many other women were elected to the council. I include in my main specification an indicator variable taking value one if at least two other female candidates were elected alongside with the marginally elected female candidate, as well as the interaction of the indicator with the treatment variable (as in Equation 2; results in Table 4). I also estimate the main specification model (Equation 1) for the two separate samples - 0 or 1 other female candidates elected and 2 or more other female candidates elected. Both estimation methods show that the main effect is stronger and largely driven by the municipalities where 2 or more other female candidates were elected alongside with the marginally elected woman. The likely reason behind the negative effect is thus the sufficiency of female representatives in the council.

31 The respective output is available from the author upon request. 
Table 4: Marginally elected women and other elected

\begin{tabular}{|c|c|c|c|c|c|}
\hline \multicolumn{6}{|c|}{ Model specifications } \\
\hline Observations & 6,088 & 4,256 & 2,314 & 1,489 & 935 \\
\hline Sample & ALL & $\begin{array}{l}\text { mandates } \\
<10\end{array}$ & $\begin{array}{l}\text { mandates } \\
<10\end{array}$ & $\begin{array}{l}\text { mandates } \\
<10\end{array}$ & $\begin{array}{l}\text { mandates } \\
<10\end{array}$ \\
\hline $\begin{array}{l}\text { Victory } \\
\text { margin }\end{array}$ & ALL & ALL & {$[-5 ; 5]$} & {$[-2 ; 2]$} & {$[-1 ; 1]$} \\
\hline \multicolumn{6}{|c|}{$\begin{array}{l}\text { Panel A } \\
\text { Number of female candidates }\end{array}$} \\
\hline Additional & $1.024^{* * *}$ & 0.388 & -0.197 & -0.283 & -0.693 \\
\hline woman & $(0.367)$ & $(0.249)$ & $(0.419)$ & $(0.551)$ & $(0.675)$ \\
\hline At least 2 & $-0.633^{*}$ & $-0.457^{*}$ & $-0.594^{*}$ & $-0.804^{*}$ & $-1.558^{* * *}$ \\
\hline $\begin{array}{l}\text { oth. wom. } \\
\text { elec. }\end{array}$ & $(0.340)$ & $(0.239)$ & $(0.357)$ & $(0.433)$ & $(0.541)$ \\
\hline *Add.wom. & & & & & \\
\hline
\end{tabular}

\section{Panel B}

Number of female candidates, excluding the marginally winning or losing female candidates

\begin{tabular}{l|l|l|l|l|l}
\hline Additional & $0.834^{* *}$ & 0.159 & -0.462 & -0.482 & -0.948 \\
woman & $(0.366)$ & $(0.246)$ & $(0.412)$ & $(0.543)$ & $(0.666)$ \\
$\begin{array}{l}\text { At least 2 } \\
\text { oth. wom. } \\
\text { elec. }\end{array}$ & $-0.576^{*}$ & $-0.436^{*}$ & -0.559 & $-0.751^{*}$ & $-1.512^{* * *}$ \\
*Add.wom. & $(0.338)$ & $(0.235)$ & $(0.351)$ & $(0.425)$ & $(0.531)$ \\
\hline
\end{tabular}

\section{Panel C}

Number of newly participating female candidates

\begin{tabular}{l|l|l|l|l|l|}
\hline Additional & $0.465^{*}$ & 0.104 & -0.399 & -0.444 & $-0.900^{*}$ \\
woman & $(0.271)$ & $(0.189)$ & $(0.310)$ & $(0.407)$ & $(0.493)$ \\
$\begin{array}{l}\text { At least } 2 \\
\text { oth. wom. }\end{array}$ & -0.401 & -0.192 & -0.314 & -0.423 & $-1.035^{* *}$ \\
elec. & $(0.255)$ & $(0.188)$ & $(0.273)$ & $(0.322)$ & $(0.406)$ \\
*Add.wom. & & & & & \\
\hline
\end{tabular}

\section{Panel D}

Number of newly participating female candidates -

municipalities with 2 or more non-marginal female candidates elected

\begin{tabular}{|l|l|l|l|l|l|}
\hline Observations & 3854 & 2250 & 1215 & 789 & 491 \\
\hline Additional & 0.019 & -0.153 & $-1.341^{* * *}$ & $-1.359^{* *}$ & $-1.810^{* *}$ \\
woman & $(0.441)$ & $(0.259)$ & $(0.429)$ & $(0.584)$ & $(0.719)$ \\
\hline
\end{tabular}

\section{Panel E}

Number of newly participating female candidates -

municipalities with none or 1 non-marginal female candidates elected

\begin{tabular}{|l|l|l|l|l|l|}
\hline Observations & 2234 & 2006 & 1099 & 700 & 444 \\
Additional & $0.540^{*}$ & 0.197 & 0.223 & 0.080 & $-0.997^{+}$ \\
woman & $(0.286)$ & $(0.230)$ & $(0.379)$ & $(0.511)$ & $(0.627)$
\end{tabular}

Note: Elections year* council size fixed effects and robust standard errors used in all regressions. ${ }^{+} P$-value $=0.112$.

Quadratic victory margin controlled for in all regressions, as well as the main effect of at least 2 non-marginal women elected in the municipality. 


\section{Robustness checks \& Extensions}

\subsection{Robustness checks}

In this section I demonstrate that my findings are not dependent on the election process in the Czech Republic. I argue that parties' decisions on candidate placement inside slates does not drive the results. I also show that there is likely to be no other characteristic of the marginal candidates apart from gender that influences other women's participation because the result holds if I control for the electorate's favourites.

First, there could be a concern that the results are driven by the partisanship of the candidate rather than the gender. Parties create slates, and therefore decide on the positioning of the candidates in the initial slate composition. Placing particular candidates on particular places on the slate could be strategic and lead to a threat to identification, since it would mean that the gender of the marginally elected candidate was likely influenced by the party.

The candidates that were elected marginally can be divided into 3 categories: 1) jumpers, who were initially placed lower than they needed in order to be elected; 2) those who were elected from the position that they initially took in their slate ranking; 3) those who were initially placed higher than the position they took in the final ranking, i.e. they were meant to be elected by their parties, but because other candidates on the slate collected more votes, the candidates in question moved down the ranking inside slate. The first category - the jumpers - are the electorate's favorites. The candidates in the third category, on the contrary, are the parties' favorites. The second category are the neutral in terms of favoritism candidates. They were placed by their parties to the not clearly electable positions, and they were not excessively favored by the electorate. Those are the candidates who were elected indeed randomly. I therefore test whether my results hold for the sample of these neutral candidates (Panels A-C of the Table B.9 in Appendix B). Overall, the results are very similar to those in the Table 4, except the main specification (Panel A), where the point estimate is both statistically and quantitatively significant only on the narrowest margin (column 5). Estimating the model separately for the municipalities where 2 or more other women were elected (Panel B) and for those that only elected 1 other woman at most (Panel C) gives same results as in the main analysis (Table 4) - I observe the negative effect on the newly participating women in the municipalities where 2 or more women were elected, and not so in those were none or 1 was elected. I therefore conclude that the parties' choices did not drive the results of the paper.

Second, from the Institutional background section we also know that voters can influence the final positioning of candidates inside slates and therefore in the sequence of mandates allocation. What could follow is that the marginal candidates happened to be marginal as a result of the extensive voting for them. They received many votes, moved higher in the mandates allocation and received the last mandate. In such case the random election of the marginal candidate could be under question. One could argue that the candidate was elected due to the electorate's preference towards him/her.

To test whether this is the case or not I do the following. I first define candidates that received enough preferential votes to move up inside their slate from their initial not electable position to an electable position as high jumpers (they comprise $1 / 3$ of all jumpers). I then create two indicator variables: 1) an indicator that the marginal winner in the municipality is a high jumper; and 2) interaction of this indicator with the treatment variable. The main effect (Panel D of Table B.9 in Appendix B) remains 
negative and significant on the margins $[-5 ; 5]$ and $[-1 ; 1]$ also if I exclude the municipalities with the high jumpers (Panel E). This indicates that the main result is not driven by the marginal candidates who are likely to be favorites of the respective electorate.

\subsection{Does partisanship matter?}

Political parties play an important role for potential politicians as a channel to become involved in politics (Reingold \& Harrell 2010). At the same time the electorate may pay higher attention to the political affiliation of candidates than to their gender (Hayes 2011). In my case an important question is whether the political affiliation of the marginally elected candidates is not the true cause of the main effect I observe.

Unlike in the United States and other countries with two-party system, there are several strong parties at the national and regional levels in the Czech Republic. Moreover, on the local level these major parties often play little role - they are not involved extensively potentially because the local politics is likely to play little role in the big politics. On the municipal level the so-called local movements tend to be more active. The distinguishing feature of local movements from major parties is the absence of a strict party ideology. Local movements are groups of local candidates who share a common view on how their municipality should function and who do not necessarily concentrate on how politics in general should work. In addition, a local movement is often created with the purpose of participating in the upcoming elections. In the next elections, the local politicians are likely to reshuffle into new local movements. It is therefore difficult to track local movements from one election to another.

Given that the difference between local movements and major parties is clear and the difference between separate local movements is less so, the test I perform is designed to check whether affiliation of the marginally elected candidates with a major party matters. The complicating factor in this analysis is the small number of such marginally winning candidates: 10 cases with the marginally winning female candidate and 9 - with the male candidates on the narrowest margin. Adding two indicator variables to the main model - the indicator that the marginally elected candidate represents a major party and its interaction with the main treatment variable - do not affect the main result on the lowest margin (Table B.10 in Appendix B).

It is also important to note that the fewer new female candidates are characteristic to the slates of the local movements, as they are prevalent in the small municipalities on the narrow margin. There are only 21 municipalities where the number of new women on major parties' slates is non-zero.

Beside major parties and local movements, individual candidates seem to play their separate role in the council. Their only observable difference is that they are on average twice less educated than the candidates that decide to participate in groups (Table 5). As candidates, their decision to position themselves separately from even local movements during elections is likely sending a specific message to the electorate, since they influence the results significantly (Panels D-F of the Table B.10 in Appendix B). Individual candidates comprise $30-50 \%$ of the marginally elected candidates on the narrow margins (Table 2). Electing individual candidates has a twice stronger effect than gender on the number of newly participating female candidates (Panel D). In the municipalities, where such candidates were elected marginally, the gender of the marginally elected candidate does not matter (Panel E). In the remainder of municipalities, gender does matter (Panel F). I conclude that my main effect is not 
driven by the individual candidates solely, nor is it driven by the candidates from regular slates.

Table 5: Basic candidates' characteristics: major party vs local movements vs individual candidates

\begin{tabular}{|l|l|l|l|l|}
\hline Variable & Mean & Std.Dev. & Min. & Max. \\
\hline Major parties: $19.82 \%$ of all candidates & 0.283 & 0.45 & 0 & 1 \\
\hline$\%$ of women & 55.481 & 13.55 & 22 & 106 \\
\hline Average age & 0.253 & 0.435 & 0 & 1 \\
\hline Share of educated & 0.327 & 0.469 & 0 & 1 \\
\hline Local movements: $74.82 \%$ of all candidates & 47.771 & 12.011 & 22 & 94 \\
\hline \% of women & 0.21 & 0.407 & 0 & 1 \\
\hline $\begin{array}{l}\text { Average age } \\
\text { Share of educated }\end{array}$ & 0.307 & 0.461 & 0 & 1 \\
\hline Individual candidates: $5.36 \%$ of all candidates & 47.336 & 11.563 & 22 & 85 \\
\hline \% of women & 0.101 & 0.302 & 0 & 1 \\
\hline Average age & Share of educated
\end{tabular}

Note: data from elections of treatment in 2002, 2006 and 2010.

\subsection{Long-term influence}

The question whether policy interventions that are supposed to address low female representation work after they are abolished is present in the literature. De Paola et al (2010) and Bhavnani (2009) find that female representation can be addressed with temporary quotas. I check whether the negative effect on the number of newly participating female candidates persists, i.e. whether it is also present in the elections in the time $t+1$ after the municipality was treated as a result of the elections in the time $t-1$.

To test the long-term effect of an additional female candidate election I first merge the 2002 elections data into the 2010 elections data and 2006 into 2014. I exclude the two marginal candidates in the elections in 2002 from the candidate pool in the elections in 2010 and the marginal candidates in 2006 from the elections in 2014. I define new female candidates in 2010 as those who did not participate in the elections in 2006 and in 2014 as those who did not participate in the elections in 2010.

The point estimate of the treatment indicator is negative, but is quantitatively lower and not statistically significant (Panels A-C of the Table B.11 in Appendix B). In the large municipalities the point estimate is positive in all specifications, but not statistically significant as well (Table B.11 in Appendix B). Either the negative effect on the number of new female participants does not persist in the longer run, or, alternatively, the coefficient is not significant due to the low number of observations and hence low predictive power.

\section{Conclusions}

In this paper I analyse Czech municipal elections data with the purpose of understanding how female political participation is affected if an additional woman is elected to the council. I estimate the local RDD using a narrow victory margin between a male and a female candidates competing for the last seat in the council. I find that in the municipalities where a female candidate was elected instead of a male candidate, 
fewer new women participate in the following elections. The participation rate of the new female candidates decreases by at least 3 percentage points, or $18 \%$. The effect is mainly driven by the municipalities where 2 or more other female candidates were elected in addition to the marginal one. These results suggests that the negative effect can be explained with the sufficient representation of women in the council.

To the best of my knowledge, the paper is the first evidence of how the gender of a local council member can affect female political participation in a society where women occupy a non-negligible share of seats in councils (close to 30\%). The study contributes to the literature by showing no evidence in support of female role models in local politics. I also show that the affiliation of a female candidate with a major party does not matter to the potential female politicians in local politics in the Czech Republic. I do not observe a long-term effect of electing an additional female councilor.

The results are robust to parties' decisions and the preferences of the electorate. The elections system in the Czech Republic, and the data, allow me to test whether the parties' decisions to place the candidates in a particular order inside slates are responsible for the main result. I am also able to test whether the effect is not driven solely by the electorate's favorite candidates, which could threaten identification. The empirical evidence goes against the two concerns.

Despite having a strong internal validity, the Regression Discontinuity Design unfortunately suffers from often weak external validity. In my case, the need to limit the data for the analysis to the municipalities with the two marginal candidates of different gender makes my sample different from the total population of municipalities in the Czech Republic in the number of active female candidates on slates. On average, more women run in elections in the municipalities used for the analysis than those that were excluded.

Although showing a strong evidence in favor of the sufficient female representation as a reason for the negative effect of electing an additional female candidate to the council on other female candidates, I am not able to reveal the entire mechanism. The data does not allow me to study whether the party leaders decide not to include new women on their slates or whether the potential female politicians decide not to run. While further research is needed to reply to this question, my analysis reveals that electing more female politicians can result in a negative side effect that the policy makers should take into account. In societies like the Czech Republic, where nearly 30\% of seats are given to women in a competitive election, an additional female councilor, instead of triggering a spillover can lead to a lower number of other women involved in local politics. It is therefore unlikely that gender parity can be reached naturally in these communities. If reaching gender parity is a goal, a policy intervention such as a gender quota may be needed.

\section{References}

Anzia S.F., Berry C.R. (2011), 'The Jackie (and Jill) Robinson effect: Why do congresswomen outperform congressmen?', American Journal of Political Science, 55 (3), 478-493.

Baltrunaite A. et al. (2014), 'Gender quotas and the quality of politicians', Journal of Public Economics, 118, 62-74.

Beaman L. et al. (2009), 'Powerful women: Does exposure reduce bias?', Quarterly Journal of Economics, 124 (4), 1497-1540. 
Beaman L. et al. (2012), 'Female leadership raises aspirations and educational attainment for girls: A policy experiment in India', Science Magazine, 335 (6068), 582-586.

Bhalotra S., Clots-Figueras I., Iyer L. (2013), 'Path-breakers: How does women's political participation respond to electoral success?', Harvard Business School Working Paper, 14-035.

Bhavnani R.R. (2009), 'Do electoral quotas 'work' after they are withdrawn? Evidence from a natural experiment in India', American Political Science Review, 103 (1), 23-35.

Brollo F., Troiano U. (2013), 'What happens when a woman wins an election? Evidence from close races in Brazil', The University of Warwick Working Paper Series, 161.

Broockman D.E. (2014), 'Can the presence of additional female politicians and candidates empower women to vote or run for office? A Regression Discontinuity approach', Electoral Studies, 34, 190-204.

Campa P. (2011), 'Gender quotas, female politicians and public expenditures: Quasiexperimental evidence', Ecompubblica Working paper series, 157.

Campbell R., Childs S., Lovenduski J. (2010), 'Do women need women representatives?', British Journal of Political Science, 40, 171-194.

Campbell D.E., Wolbrecht C. (2006), 'See Jane run: Women politicians as role models for adolescents', The Journal of Politics, 68 (2), 233-247.

Chattopadhyay R., Duflo E. (2004), 'Women as policy makers: Evidence from a randomized policy experiment in India', Econometrica, 72 (5), 1409-1443.

Chen L.-J. (2010), 'Do gender quotas influence women's representation and policies?', European Journal of Comparative economics, 7 (1), 13-30.

Clayton A. (2015), 'Women's political engagement under quota-mandated female representation: Evidence from a randomized policy experiment', Comparative Political Studies, 48 (3), 333-369.

Clots-Figueras I. (2011), 'Women in politics. Evidence from the Indian states', Journal of Public Economics, 95, 664-690.

Cunat V., Gine M., Guadalupe M. (2012), 'The vote is cast: The effect of corporate governance on shareholder value', The Journal of Finance, 67(5), 1943-1977.

De Paola M., Lombardo R., Scoppa V. (2010), 'Can gender quotas break down negative stereotypes? Evidence from changes in electoral rules', Journal of Public Economics, 94 (5-6), 344353.

Deininger K. et al. (2015), 'Does female reservation affect long-term political outcomes? Evidence from rural India', The Journal of Development Studies, 51 (1), 32-49.

Eggers A. (2011), 'Is female political participation self-reinforcing? Evidence from French municipal politics', mimeo.

Esteve-Volart B., Bagues M. (2012), 'Are women pawns in the political game? Evidence from elections to the Spanish senate', Journal of Public Economics, 96 (3-4), 387-399.

European Commission (2013), 'Women and men in leadership positions in the European Union', European Commission at <http://ec.europa.eu/justice/gender-equality/files /gender_balance_decision_making/131011_women_men_leadership_en.pdf $>$.

Ferreira F., Gyourko J. (2014), 'Does gender matter for political leadership? The case of U.S. Mayors', Journal of Public Economics, 112, 24-39.

Freier R., Odendahl C. (2012), 'Do parties matter? Estimating the effect of political power in multi-party systems', Discussion Paper of DIW Berlin, 1205.

Gilardi F. (2015), 'The temporary importance of role models for women's political representation', American Journal of Political Science, 59(4), 957-970.

Hayes D. (2011), 'When gender and party collide: Stereotyping in candidate trait attribution', Politics \& Gender, 7, 133-165. 
Imbens G.W., Lemieux T. (2008), 'Regression discontinuity design: A guide to practice', Journal of Econometrics, 142 (2), 615-635.

Joshi N.K. (2015), 'Party politics, governors, and healthcare expenditures', Economics \& Politics, 27 (1), 53-77.

Jurajda S., Munich D. (2015), 'Candidate ballot information and election outcomes: the Czech case', Post-Soviet Affairs, 31, 448-469.

Lee D.S. (2008), 'Randomized experiments from non-random selection in U.S. House elections', Journal of Econometrics, 142, 675-697.

Migueis M. (2013), 'The effect of political alignment on transfers to Portuguese municipalities', Economics \& Politics, 25 (1), 110-133.

Murray R. (2008), 'Is the mere presence of a strong female candidate enough to increase the substantive representation of women?', Parliamentary Affairs, 61 (3), 476-489.

Palguta J. (2013), Nonlinear Incentive Schemes and Corruption in Public Procurement: Evidence from the Czech Republic', CERGE-EI Working Paper Series, Working Paper 483.

Palguta J. (2014), 'Concealed Ownership of Contractors, Manipulation of Tenders and the Allocation of Public Procurement Contracts', CERGE-EI Working Paper Series, Working Paper 501.

Palguta J. (2015), 'Political Rent-Seeking in Public Procurement: Evidence from the Entry of Political Challengers at Electoral Thresholds', CERGE-EI Working Paper Series, Working Paper 549.

Pettersson-Lidbom P. (2008), 'Do parties matter for economic outcomes? A RegressionDiscontinuity approach', Journal of the European Economic Association, 6 (5), 1037-1056.

Redmond P., Regan J. (2015), 'Incumbency advantage in a proportional electoral system: A Regression Discontinuity analysis of Irish elections', European Journal of Political Economy, 38, 244-256.

Reingold B., Harrell J. (2010), 'The impact of descriptive representation on women's political engagement', Political Research Quarterly, 63 (2), 280-294.

Smith A.R., Reingold B., Owens M.L. (2012), 'The political determinants of women's descriptive representation in cities', Political Research Quarterly, 65 (2), 315-329.

Swers M. (2002), 'Research of women in legislatures: What have we learned, where are we going?', Women \& Politics, 23 (1-2), 167-185.

Trounstine J. (2011), 'Evidence of a local incumbency advantage', Legislative Studies Quarterly, XXXVI (2), 255-280.

Wangnerud L. (2000), 'Testing the politics of presence: Women's representation in the Swedish Riksdag', Scandinavian Political Studies, 23 (1), 67-91.

Weeks A.C., Baldez L. (2015), 'Quotas and qualifications: The impact of gender quota laws on the qualifications of legislators in the Italian parliament', European Political Science Review, 7 (1), 119-144.

Wolak J. (2015), 'Candidate gender and the political engagement of women and men', American Politics Research, 43 (5), 872-896.

Wolbrecht C., Campbell D.E. (2007), 'Leading by example: Female members of parliament as political role models', American Journal of Political Science, 51 (4), 921-939. 


\section{Appendixes}

\section{Appendix A: D'Hondt's method}

This method has number of modifications and is widely used. In the Czech Republic the method has been used to allocate the mandates in the municipal council elections since 1990, the regional elections since 2000, the national elections since 2002 and in the European Parliament elections since 2004. The method works in the following way.

Example:

Mandates to be allocated: 4

Votes cast to party A: 21529

Votes cast to party B: 64583

Votes cast to party C: 21527

Votes cast to party D: 16124

The essence of the method is that the total number of votes cast to each party is divided by the set of numbers ("electoral divisors") to obtain the so called Shares. Since 2001 the divisors are: 1, 2, 3, 4, 5 etc.

Example:

Assume each party has nominated four candidates. Then the shares are:

Shares A: 21529, 10765, 7177, 5383

Shares B: 64583, 32292, 21528, 16146

Shares C: $21527,10764,7176,5382$

Shares D: $16124,8062,5375,4031$

These Shares are then ranked from highest to lowest. The necessary amount of mandates $\mathrm{N}$ is allocated to the parties that occupy the first $\mathrm{N}$ positions.

Example:

1. $64583 \mathrm{~B}$

2. $32292 \mathrm{~B}$

3. $21529 \mathrm{~A}$

4. $21528 \mathrm{~B}$

In order to participate in the allocation of mandates, a slate needs to collect at least $5 \%$ of total amount of votes that were allocated to the candidates in the municipality. In case the slate is represented by fewer candidates than the amount of mandates to be allocated, the condition is adjusted: the slate needs to accumulate $5 \%$ of the following number. Total amount of votes cast to all candidates in the municipality are divided by the amount of mandates to be allocated and multiplied by the number of candidates representing the slate. Therefore, the slates that nominate fewer candidates than have to be elected in the municipality have to accumulate fewer votes than $5 \%$ of total amount to participate in the allocation of mandates.

The mandates allocated to the party are distributed to the candidates inside the party slate according to their positions on the slate. In case a candidate receives $10 \%$ more votes than average amount of votes per candidate on the slate, the candidate moves up inside the slate.

\section{Calculating Victory Margin}

I express victory margin in terms of the share of voters who came to vote in the respective elections. It can be interpreted in the following way: if more voters, the 
number of them corresponding to the share of total voters who did come to vote, came additionally and voted for the marginal loser or the marginal loser's slate such that it would not change the final ranking of candidates in the slate that happened without these additional votes, then the marginal loser would had been elected, and the marginal winner would not have been elected.

As described above, to rank the candidates for the mandates allocation the socalled Shares are calculated. The Share assigned to a given candidate is calculated as the total number of votes received by his/her slate divided by the final position of the candidate on slate (Equation A.1).

Share $=\frac{\text { Total Number of Votes Cast To The Slate }}{\text { Final Position Of Candidate On Slate }}$

In order to express the victory margin in the share of voters that came to vote, I first need to return to the number of votes cast to the slate, then divide it by the number of mandates to calculate how many voters that number of votes corresponds to, and finally find the share that this number of voters take in the total number of voters (Equation A.2).

Votes Share $=\frac{\text { Share } * \frac{\text { Final Position Of Marginal Loser On Slate }}{\text { Mandates }}}{\text { Voters }}$

Finally, I calculate victory margin as the difference between votes shares of the marginal winner and loser (Equation A.3).

Victory Margin $=$ Votes Share winner - Votes Share $_{\text {loser }}$ 


\section{Appendix B: Additional Tables and Figures}

Table B.1: Summary statistics: Comparison of municipalities of interest (marginal candidates of different gender) with the excluded municipalities (marginal candidates of the same gender)

\begin{tabular}{|c|c|c|c|c|}
\hline Variable & Mean & Std.Dev. & Min. & Max. \\
\hline \multicolumn{5}{|c|}{ All EDs } \\
\hline \multicolumn{5}{|c|}{ EDs with marginal candidates of different gender; $N r$ of EDs 6,088} \\
\hline Total number of candidates & 35.296 & 46.35 & 6 & 584 \\
\hline Number of female candidates & 11.173 & 15.52 & 1 & 188 \\
\hline $\begin{array}{l}\text { Number of elected female candidates (excl. } \\
\text { marginal) }\end{array}$ & 2.253 & 1.713 & 0 & 13 \\
\hline Median position of female candidates on slates & 0.305 & 0.195 & 0 & 0.889 \\
\hline Share of votes cast to female candidates & 0.301 & 0.117 & 0 & 0.91 \\
\hline \multicolumn{5}{|c|}{ EDs with marginal candidates of the same gender; $N r$ of EDs 9,577 } \\
\hline Total number of candidates & 35.199 & 48.121 & 6 & 867 \\
\hline Number of female candidates & 10.092 & 15.762 & 0 & 288 \\
\hline $\begin{array}{l}\text { Number of elected female candidates (excl. } \\
\text { marginal) }\end{array}$ & 2.289 & 1.752 & 0 & 18 \\
\hline Median position of female candidates on slates & 0.289 & 0.213 & 0 & 0.889 \\
\hline Share of votes cast to female candidates & 0.246 & 0.13 & 0 & 1 \\
\hline \multicolumn{5}{|c|}{ Mandates $<10$, victory margin $[-5 ; 5]$} \\
\hline \multicolumn{5}{|c|}{ EDs with marginal candidates of different gender; $N r$ of EDs 2,314 } \\
\hline Total number of candidates & 19.106 & 11.1 & 6 & 90 \\
\hline Number of female candidates in ED & 6.063 & 4.350 & 1 & 46 \\
\hline $\begin{array}{l}\text { Number of elected female candidates (excl. } \\
\text { marginal) }\end{array}$ & 1.654 & 1.14 & 0 & 7 \\
\hline Median position of female candidates on slates & 0.211 & 0.209 & 0 & 0.806 \\
\hline Share of votes cast to female candidates & 0.299 & 0.124 & 0.038 & 0.91 \\
\hline \multicolumn{5}{|c|}{ EDs with marginal candidates of the same gender; $N r$ of EDs 3,764 } \\
\hline Total number of candidates & 18.704 & 11.132 & 6 & 88 \\
\hline Number of female candidates in ED & 4.913 & 4.319 & 0 & 35 \\
\hline $\begin{array}{l}\text { Number of elected female candidates (excl. } \\
\text { marginal) }\end{array}$ & 1.711 & 1.236 & 0 & 7 \\
\hline Median position of female candidates on slates & 0.193 & 0.209 & 0 & 0.833 \\
\hline Share of votes cast to female candidates & 0.236 & 0.137 & 0 & 0.806 \\
\hline \multicolumn{5}{|c|}{ Mandates $<10$, victory margin $[-2 ; 2]$} \\
\hline \multicolumn{5}{|c|}{ EDs with marginal candidates of different gender; Nr. of EDs 1,489 } \\
\hline Total number of candidates & 18.799 & 11.452 & 6 & 90 \\
\hline Number of female candidates in ED & 5.985 & 4.507 & 1 & 46 \\
\hline $\begin{array}{l}\text { Number of elected female candidates (excl. } \\
\text { marginal) }\end{array}$ & 1.656 & 1.131 & 0 & 7 \\
\hline Median position of female candidates on slates & 0.175 & 0.207 & 0 & 0.786 \\
\hline Share of votes cast to female candidates & 0.299 & 0.125 & 0.038 & 0.777 \\
\hline \multicolumn{5}{|c|}{ EDs with marginal candidates of the same gender; $N r$ of EDs 2,468 } \\
\hline Total number of candidates & 18.548 & 11.573 & 6 & 88 \\
\hline Number of female candidates in ED & 4.839 & 4.428 & 0 & 35 \\
\hline
\end{tabular}




\begin{tabular}{|c|c|c|c|c|}
\hline Variable & Mean & Std.Dev. & Min. & Max. \\
\hline $\begin{array}{l}\text { Number of elected female candidates (excl. } \\
\text { marginal) }\end{array}$ & 1.709 & 1.241 & 0 & 7 \\
\hline Median position of female candidates on slates & 0.162 & 0.205 & 0 & 0.833 \\
\hline Share of votes cast to female candidates & 0.234 & 0.136 & 0 & 0.806 \\
\hline \multicolumn{5}{|c|}{ Mandates $<10$, victory margin $[-1 ; 1]$} \\
\hline \multicolumn{5}{|c|}{ EDs with marginal candidates of different gender; Nr. of EDs 935} \\
\hline Total number of candidates & 18.513 & 11.684 & 6 & 90 \\
\hline Number of female candidates in ED & 5.887 & 4.565 & 1 & 46 \\
\hline $\begin{array}{l}\text { Number of elected female candidates (excl. } \\
\text { marginal) }\end{array}$ & 1.653 & 1.119 & 0 & 6 \\
\hline Median position of female candidates on slates & 0.151 & 0.201 & 0 & 0.786 \\
\hline Share of votes cast to female candidates & 0.302 & 0.126 & 0.053 & 0.777 \\
\hline \multicolumn{5}{|c|}{ EDs with marginal candidates of the same gender; Nr. of EDs 1,601 } \\
\hline Total number of candidates & 18.3 & 11.875 & 6 & 88 \\
\hline Number of female candidates in ED & 4.79 & 4.583 & 0 & 35 \\
\hline $\begin{array}{l}\text { Number of elected female candidates (excl. } \\
\text { marginal) }\end{array}$ & 1.711 & 1.243 & 0 & 7 \\
\hline Median position of female candidates on slates & 0.138 & 0.198 & 0 & 0.833 \\
\hline Share of votes cast to female candidates & 0.233 & 0.137 & 0 & 0.806 \\
\hline
\end{tabular}


Table B.2: Summary statistics: EDs that are excluded from the sample

\begin{tabular}{|c|c|c|c|c|}
\hline Variable & Mean & Std.Dev. & Min. & Max. \\
\hline \multicolumn{5}{|c|}{ Panel B: EDs with same gender candidates competing for the last seat, $\mathrm{N}=9,577$} \\
\hline Number of candidates in ED & 36.85 & 52.933 & 5 & 971 \\
\hline Number of female candidates in ED & 11.326 & 17.957 & 0 & 325 \\
\hline Number of seats in a Council & 10.027 & 4.874 & 5 & 55 \\
\hline Number of slates in ED & 4.631 & 3.743 & 1 & 39 \\
\hline Number of slates in ED in previous elections & 4.749 & 3.687 & 1 & 39 \\
\hline
\end{tabular}

Panel C: EDs with same gender candidates competing for the last seat, mandates $<10$, victory margin $[-5 ; 5], \mathrm{N}=3,764$

\begin{tabular}{l|l|l|l|l} 
Number of candidates in ED & 18.366 & 11.936 & 5 & 99 \\
Number of female candidates in ED & 5.313 & 4.688 & 0 & 46 \\
Number of seats in a Council & 7.678 & 1.161 & 5 & 9 \\
Number of slates in ED & 5.574 & 4.251 & 1 & 25 \\
Number of slates in ED in previous elections & 6.288 & 4.205 & 2 & 25 \\
\hline
\end{tabular}

Panel D: EDs with same gender candidates competing for the last seat, mandates $<10$, victory margin [-2;2], $\mathrm{N}=2,468$

\begin{tabular}{|l|l|l|l|l|} 
Number of candidates in ED & 17.936 & 11.801 & 5 & 90 \\
\hline Number of female candidates in ED & 5.183 & 4.627 & 0 & 46 \\
\hline Number of seats in a Council & 7.68 & 1.133 & 5 & 9 \\
\hline Number of slates in ED & 6.310 & 4.492 & 1 & 25 \\
\hline Number of slates in ED in previous elections & 7.373 & 4.431 & 2 & 25 \\
\hline
\end{tabular}

Panel E: EDs with same gender candidates competing for the last seat, mandates $<10$,

Number of candidates in ED victory margin $[-1 ; 1], \mathrm{N}=1,601$

Number of female candidates in ED

Number of seats in a Council

Number of slates in ED

Number of slates in ED in previous elections

\begin{tabular}{|l|l|l|l|}
17.611 & 11.731 & 5 & 90 \\
5.098 & 4.672 & 0 & 46 \\
7.709 & 1.121 & 5 & 9 \\
6.845 & 4.711 & 1 & 25 \\
8.154 & 4.579 & 2 & 25
\end{tabular}


Table B.3: Summary statistics: EDs that are excluded from the sample: two marginal female candidates

\section{Variable}

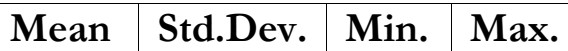

Panel B: EDs with female candidates competing for the last seat, $\mathrm{N}=1,199$

Number of candidates in ED

Number of female candidates in ED

Number of seats in a Council

Number of slates in ED

Number of slates in ED in previous elections

\begin{tabular}{l|l|l|l|}
31.158 & 38.169 & 5 & 344 \\
10.976 & 13.607 & 0 & 137 \\
9.488 & 4.2 & 5 & 45 \\
4.314 & 3.534 & 1 & 23 \\
4.513 & 3.543 & 1 & 23 \\
\hline
\end{tabular}

Panel C: EDs with female candidates competing for the last seat, mandates $<10$, victory margin $[-5 ; 5], \mathrm{N}=474$

Number of candidates in ED

Number of female candidates in ED

Number of seats in a Council

Number of slates in ED

Number of slates in ED in previous elections

\begin{tabular}{l|l|l|l|}
18.023 & 11.449 & 5 & 63 \\
6.399 & 4.795 & 0 & 29 \\
7.677 & 1.166 & 5 & 9 \\
5.477 & 4.317 & 1 & 23 \\
6.255 & 4.236 & 2 & 20 \\
\hline
\end{tabular}

Panel D: EDs with female candidates competing for the last seat, mandates $<10$, victory margin [-2;2], $\mathrm{N}=306$

\begin{tabular}{l|l|l|l|l} 
Number of candidates in ED & 17.438 & 11.564 & 5 & 63 \\
Number of female candidates in ED & 6.248 & 4.851 & 0 & 29 \\
Number of seats in a Council & 7.657 & 1.135 & 5 & 9 \\
Number of slates in ED & 6.464 & 4.631 & 1 & 23 \\
Number of slates in ED in previous elections & 7.575 & 4.418 & 2 & 20 \\
\hline
\end{tabular}

Panel D: EDs with female candidates competing for the last seat, mandates $<10$, victory margin [-2;2], $\mathrm{N}=196$

Number of candidates in ED

Number of female candidates in ED

Number of seats in a Council

Number of slates in ED

Number of slates in ED in previous elections

\begin{tabular}{l|l|l|l}
17.316 & 11.817 & 6 & 63 \\
6.173 & 4.883 & 0 & 27 \\
7.699 & 1.157 & 5 & 9 \\
7.122 & 4.9 & 1 & 23 \\
8.495 & 4.519 & 2 & 20
\end{tabular}


Table B.4: Summary statistics: EDs that are excluded from the sample: two marginal male candidates

\begin{tabular}{|l|l|l|l|l|}
\hline Variable & Mean & Std.Dev. & Min. & Max. \\
\hline \multicolumn{1}{|c|}{ Panel B: EDs with male candidates competing for the last seat, N=8,378 } \\
Number of candidates in ED & 37.665 & 54.675 & 5 & 971 \\
Number of female candidates in ED & 11.376 & 18.496 & 0 & 325 \\
Number of seats in a Council & 10.105 & 4.958 & 5 & 55 \\
Number of slates in ED & 4.677 & 3.77 & 1 & 39 \\
Number of slates in ED in previous elections & 4.783 & 3.706 & 1 & 39 \\
\hline
\end{tabular}

Panel C: EDs with male candidates competing for the last seat, mandates $<10$, victory margin $[-5 ; 5], N=3,290$

Number of candidates in ED

Number of female candidates in ED

Number of seats in a Council

Number of slates in ED

Number of slates in ED in previous elections

\begin{tabular}{l|l|l|l|}
18.416 & 12.006 & 5 & 99 \\
5.157 & 4.652 & 0 & 46 \\
7.678 & 1.16 & 5 & 9 \\
5.588 & 4.242 & 1 & 25 \\
6.293 & 4.201 & 2 & 25 \\
\hline
\end{tabular}

Panel D: EDs with male candidates competing for the last seat, mandates $<10$, victory margin [-2;2], $\mathrm{N}=2,162$

\begin{tabular}{l|l|l|l|l} 
Number of candidates in ED & 18.007 & 11.835 & 5 & 90 \\
Number of female candidates in ED & 5.032 & 4.575 & 0 & 46 \\
Number of seats in a Council & 7.683 & 1.133 & 5 & 9 \\
Number of slates in ED & 6.289 & 4.472 & 1 & 25 \\
Number of slates in ED in previous elections & 7.344 & 4.433 & 2 & 25 \\
\hline
\end{tabular}

Panel E: EDs with male candidates competing for the last seat, mandates $<10$, victory

$$
\text { margin [-1;1], } \mathrm{N}=1,405
$$

Number of candidates in ED

Number of female candidates in ED

Number of seats in a Council

Number of slates in ED

Number of slates in ED in previous elections

\begin{tabular}{|l|l|l|l|}
17.652 & 11.723 & 5 & 90 \\
4.948 & 4.623 & 0 & 46 \\
7.71 & 1.116 & 5 & 9 \\
6.806 & 4.684 & 1 & 25 \\
8.106 & 4.587 & 2 & 25
\end{tabular}


Table B.5: Summary statistics: female political participation evolution

\begin{tabular}{|c|c|c|c|c|c|}
\hline Year & Variable & Mean & Std.Dev. & Min. & Max. \\
\hline \multirow[t]{12}{*}{2002} & All EDs: 6,319 & & & & \\
\hline & Number of female candidates in ED & 8.204 & 13.822 & 0 & 245 \\
\hline & Share of female candidates in ED & 0.253 & 0.134 & 0 & 0.8 \\
\hline & $\begin{array}{l}\text { Number of elected female candidates in } \\
\text { ED }\end{array}$ & 2.219 & 1.702 & 0 & 14 \\
\hline & Share of elected female candidates in ED & 0.229 & 0.154 & 0 & 0.857 \\
\hline & $\begin{array}{l}\text { Median position of female candidates on } \\
\text { slates }\end{array}$ & 0.256 & 0.215 & 0 & 0.909 \\
\hline & Small EDs: 4,560 & & & & \\
\hline & Number of female candidates in ED & 3.616 & 3.217 & 0 & 40 \\
\hline & Share of female candidates in ED & 0.244 & 0.146 & 0 & 0.8 \\
\hline & $\begin{array}{l}\text { Number of elected female candidates in } \\
\text { ED }\end{array}$ & 1.7 & 1.242 & 0 & 7 \\
\hline & Share of elected female candidates in ED & 0.228 & 0.166 & 0 & 0.857 \\
\hline & $\begin{array}{l}\text { Median position of female candidates on } \\
\text { slates }\end{array}$ & 0.214 & 0.221 & 0 & 0.889 \\
\hline \multirow[t]{12}{*}{2006} & All EDs 6,350 & & & & \\
\hline & Number of female candidates in ED & 9.321 & 15.263 & 0 & 475 \\
\hline & Share of female candidates in ED & 0.28 & 0.136 & 0 & 1 \\
\hline & $\begin{array}{l}\text { Number of elected female candidates in } \\
\text { ED }\end{array}$ & 2.444 & 1.775 & 0 & 18 \\
\hline & Share of elected female candidates in ED & 0.254 & 0.159 & 0 & 1 \\
\hline & $\begin{array}{l}\text { Median position of female candidates on } \\
\text { slates }\end{array}$ & 0.288 & 0.21 & 0 & 0.889 \\
\hline & Small EDs 4,604 & & & & \\
\hline & Number of female candidates in ED & 4.336 & 3.822 & 0 & 46 \\
\hline & Share of female candidates in ED & 0.273 & 0.15 & 0 & 1 \\
\hline & $\begin{array}{l}\text { Number of elected female candidates in } \\
\text { ED }\end{array}$ & 1.895 & 1.278 & 0 & 7 \\
\hline & Share of elected female candidates in ED & 0.255 & 0.172 & 0 & 1 \\
\hline & $\begin{array}{l}\text { Median position of female candidates on } \\
\text { slates }\end{array}$ & 0.249 & 0.221 & 0 & 0.889 \\
\hline \multirow[t]{11}{*}{2010} & All EDs 6,353 & & & & \\
\hline & Number of female candidates in ED & 11.042 & 17.56 & 0 & 288 \\
\hline & Share of female candidates in ED & 0.298 & 0.133 & 0 & 1 \\
\hline & $\begin{array}{l}\text { Number of elected female candidates in } \\
\text { ED }\end{array}$ & 2.563 & 1.786 & 0 & 18 \\
\hline & Share of elected female candidates in ED & 0.269 & 0.16 & 0 & 1 \\
\hline & $\begin{array}{l}\text { Median position of female candidates on } \\
\text { slates }\end{array}$ & 0.337 & 0.206 & 0 & 0.889 \\
\hline & Small EDs 4,620 & & & & \\
\hline & Number of female candidates in ED & 4.974 & 4.224 & 0 & 35 \\
\hline & Share of female candidates in ED & 0.293 & 0.147 & 0 & 1 \\
\hline & $\begin{array}{l}\text { Number of elected female candidates in } \\
\text { ED }\end{array}$ & 2.019 & 1.276 & 0 & 8 \\
\hline & Share of elected female candidates in ED & 0.274 & 0.174 & 0 & 1 \\
\hline
\end{tabular}




\begin{tabular}{|c|c|c|c|c|c|}
\hline Year & Variable & Mean & Std.Dev. & Min. & Max. \\
\hline & $\begin{array}{l}\text { Median position of female candidates on } \\
\text { slates }\end{array}$ & 0.308 & 0.224 & 0 & 0.889 \\
\hline \multirow[t]{12}{*}{2014} & All EDs 6,359 & & & & \\
\hline & Number of female candidates in ED & 11.777 & 20.466 & 0 & 325 \\
\hline & Share of female candidates in ED & 0.309 & 0.135 & 0 & 1 \\
\hline & $\begin{array}{l}\text { Number of elected female candidates in } \\
\text { ED }\end{array}$ & 2.637 & 1.807 & 0 & 19 \\
\hline & Share of elected female candidates in ED & 0.278 & 0.161 & 0 & 1 \\
\hline & $\begin{array}{l}\text { Median position of female candidates on } \\
\text { slates }\end{array}$ & 0.341 & 0.201 & 0 & 0.889 \\
\hline & Small EDs 4,636 & & & & \\
\hline & Number of female candidates in ED & 5.109 & 4.332 & 0 & 38 \\
\hline & Share of female candidates in ED & 0.305 & 0.15 & 0 & 1 \\
\hline & $\begin{array}{l}\text { Number of elected female candidates in } \\
\text { ED }\end{array}$ & 2.092 & 1.288 & 0 & 8 \\
\hline & Share of elected female candidates in ED & 0.284 & 0.174 & 0 & 1 \\
\hline & $\begin{array}{l}\text { Median position of female candidates on } \\
\text { slates }\end{array}$ & 0.314 & 0.22 & 0 & 0.889 \\
\hline
\end{tabular}


Table B.6: Co-variate balance check

Model specifications

\begin{tabular}{|l|l|l|l|l|l|}
\hline Observations & $\mathbf{5 , 9 5 1}$ & $\mathbf{4 , 2 2 4}$ & $\mathbf{2 , 2 9 2}$ & $\mathbf{1 , 4 7 7}$ & $\mathbf{9 2 5}$ \\
\hline Sample & ALL & $\begin{array}{l}\text { mandates } \\
<10\end{array}$ & $\begin{array}{l}\text { mandates } \\
<10\end{array}$ & $\begin{array}{l}\text { mandates } \\
<10\end{array}$ & $\begin{array}{l}\text { mandates } \\
<10\end{array}$ \\
\hline $\begin{array}{l}\text { Victory } \\
\text { margin }\end{array}$ & ALL & ALL & {$[-5 ; 5]$} & {$[-2 ; 2]$} & {$[-1 ; 1]$} \\
\hline
\end{tabular}

Panel A. Demographic indicators

(two-year average - year of elections of treatment and the previous year)

\begin{tabular}{|c|c|c|c|c|c|}
\hline \multicolumn{6}{|c|}{ Number of inhabitants } \\
\hline Additional & 1.966 & 4.700 & 8.201 & 37.460 & 36.715 \\
\hline woman & (79.383) & $(14.575)$ & (22.793) & (28.221) & (35.894) \\
\hline \multicolumn{6}{|c|}{ Number of children born per year } \\
\hline Additional & 0.002 & -0.041 & -0.327 & -0.218 & 0.136 \\
\hline woman & $(0.880)$ & $(0.180)$ & $(0.292)$ & $(0.366)$ & $(0.438)$ \\
\hline
\end{tabular}

\section{Panel B. Local budget indicators}

(two-year average - year of elections of treatment and the previous year)

Total local budget spending per inhabitant

\begin{tabular}{l|l|l|l|l|l} 
Additional & 267.212 & 854.281 & $2340.134^{*}$ & -103.374 & 1004.588 \\
woman & $(637.118)$ & $(753.905)$ & $(1224.506)$ & $(1603.390)$ & $(1945.379)$
\end{tabular}

Current local budget spending per inhabitant

\begin{tabular}{l|l|l|l|l|l|} 
Additional & 49.786 & 469.026 & 891.646 & -772.339 & -636.782 \\
woman & $(474.321)$ & $(451.610)$ & $(712.698)$ & $(890.245)$ & $(1089.825)$
\end{tabular}

\begin{tabular}{l|l|l|l|l|l|}
\multicolumn{7}{c}{ Capital local budget spending per inhabitant } \\
Additional & 217.426 & 385.255 & $1448.488^{*}$ & 668.966 & 1641.370 \\
woman & $(353.587)$ & $(500.719)$ & $(811.423)$ & $(1095.932)$ & $(1357.086)$ \\
\hline \multicolumn{7}{|c|}{ Subsidies received by the municipality per inhabitant } \\
Additional & 393.091 & $853.876^{*}$ & $1873.230^{* *}$ & 616.268 & 1825.595 \\
woman & $(488.861)$ & $(495.218)$ & $(794.054)$ & $(1053.125)$ & $(1215.759)$
\end{tabular}

\begin{tabular}{l|l|l|l|l|l|}
\multicolumn{7}{c|}{ Local budget tax income per inhabitant } \\
Additional & 54.241 & 76.038 & -447.636 & $-1126.803^{*}$ & -1343.785 \\
woman & $(161.190)$ & $(250.586)$ & $(412.895)$ & $(637.464)$ & $(861.475)$
\end{tabular}

\begin{tabular}{l|l|l|l|l|l|}
\multicolumn{7}{c}{ Local budget non-tax income per inhabitant } \\
Additional & 111.066 & 161.405 & 251.835 & -0.514 & 417.316 \\
woman & $(147.495)$ & $(205.911)$ & $(305.962)$ & $(304.735)$ & (362.771)
\end{tabular}

\begin{tabular}{l|l|l|l|l|l}
\multicolumn{7}{c}{ Local budget capital income per inhabitant } \\
Additional & $-343.733^{* * *}$ & $-423.667^{* *}$ & 80.839 & 92.658 & -60.723 \\
woman & $(120.496)$ & $(181.727)$ & $(256.255)$ & $(257.178)$ & $(307.176)$ \\
\hline
\end{tabular}

Panel C. Share of votes cast to major parties in the previous elections (elections of treatment)

\begin{tabular}{l|l|l|l|l|l} 
Additional & 0.004 & 0.002 & -0.001 & -0.004 & -0.010 \\
woman & $(0.005)$ & $(0.006)$ & $(0.009)$ & $(0.012)$ & $(0.015)$ \\
\hline
\end{tabular}

Panel D. Median age of candidates in the previous elections (elections of treatment) Median age of all candidates (excluding the two marginal)

\begin{tabular}{l|l|l|l|l|l|} 
Additional & 0.256 & 0.373 & -0.757 & -0.917 & -0.541 \\
woman & $(0.230)$ & $(0.333)$ & $(0.532)$ & $(0.765)$ & $(1.022)$ \\
Median age of female candidates (excluding the marginal) \\
Additional & 0.197 & 0.366 & -1.067 & -0.746 & 0.157 \\
woman & $(0.451)$ & $(0.686)$ & $(1.023)$ & $(1.527)$ & $(2.121)$
\end{tabular}




\begin{tabular}{|c|c|c|c|c|c|}
\hline Observations & 5,951 & 4,224 & 2,292 & 1,477 & 925 \\
\hline Sample & ALL & $\begin{array}{l}\text { mandates } \\
<10\end{array}$ & $\begin{array}{l}\text { mandates } \\
<10\end{array}$ & $\begin{array}{l}\text { mandates } \\
<10\end{array}$ & $\begin{array}{l}\text { mandates } \\
<10\end{array}$ \\
\hline $\begin{array}{l}\text { Victory } \\
\text { margin }\end{array}$ & ALL & ALL & {$[-5 ; 5]$} & {$[-2 ; 2]$} & {$[-1 ; 1]$} \\
\hline \multicolumn{6}{|c|}{ Median age of elected candidates (excluding the marginal) } \\
\hline Additional & 0.361 & 0.364 & -0.716 & -0.429 & -0.299 \\
\hline woman & $(0.239)$ & $(0.349)$ & $(0.555)$ & $(0.789)$ & (1.048) \\
\hline
\end{tabular}

Median age of elected female candidates (excluding the marginal)

\begin{tabular}{l|l|l|l|l|l} 
Additional & $1.206^{*}$ & $1.784^{*}$ & -2.146 & -0.950 & 1.430 \\
woman & $(0.677)$ & $(1.020)$ & $(1.637)$ & $(2.364)$ & $(3.165)$ \\
\hline \multicolumn{5}{c}{ Panel E. Share of educated candidates in the previous elections (elections of treatment) } \\
Share of educated candidates among all candidates (excluding the two margina \\
Additional & 0.007 & 0.005 & 0.005 & 0.016 & -0.001 \\
woman & $(0.005)$ & $(0.006)$ & $(0.010)$ & $(0.013)$ & $(0.017)$
\end{tabular}

Share of educated female candidates among all female candidates (excluding the marginal)

\begin{tabular}{l|l|l|l|l|l|} 
Additional & 0.010 & 0.010 & 0.005 & 0.020 & 0.020 \\
woman & $(0.008)$ & $(0.011)$ & $(0.018)$ & $(0.027)$ & $(0.034)$
\end{tabular}

Share of educated candidates among elected candidates (excluding the marginal)

\begin{tabular}{l|l|l|l|l|l} 
Additional & $0.017^{* *}$ & $0.016^{*}$ & 0.017 & 0.032 & 0.015 \\
woman & $(0.008)$ & $(0.010)$ & $(0.015)$ & $(0.021)$ & $(0.026)$
\end{tabular}

Share of educated female candidates among elected female candidates (excluding the marginal)

\begin{tabular}{l|l|l|l|l|l} 
Additional & 0.018 & 0.022 & 0.025 & 0.060 & 0.076 \\
woman & $(0.013)$ & $(0.017)$ & $(0.027)$ & $(0.038)$ & $(0.051)$ \\
\hline
\end{tabular}

Panel F. Female political participation in the previous elections (elections of treatment)

Number of female candidates

\begin{tabular}{l|l|l|l|l|l|} 
Additional & $0.667^{*}$ & 0.039 & -0.367 & -0.077 & -0.186 \\
woman & $(0.357)$ & $(0.228)$ & $(0.400)$ & $(0.582)$ & $(0.775)$
\end{tabular}

Share of female candidates

\begin{tabular}{l|l|l|l|l|l} 
Additional & 0.004 & -0.002 & -0.007 & 0.009 & 0.016 \\
woman & $(0.005)$ & $(0.007)$ & $(0.011)$ & $(0.015)$ & $(0.021)$
\end{tabular}

\begin{tabular}{l|l|l|l|l|l|}
\multicolumn{7}{c}{ Number of elected female candidates (excluding the marginal) } \\
Additional & 0.079 & 0.040 & -0.123 & -0.051 & 0.274 \\
woman & $(0.060)$ & $(0.062)$ & $(0.099)$ & $(0.135)$ & $(0.173)$
\end{tabular}

Median position of female candidates on slates

\begin{tabular}{l|l|l|l|l|l} 
Additional & -0.003 & -0.006 & -0.023 & -0.031 & -0.046 \\
woman & $(0.007)$ & $(0.011)$ & $(0.017)$ & $(0.025)$ & $(0.032)$
\end{tabular}

Share of votes cast to female candidates in the municipality

\begin{tabular}{l|l|l|l|l|l|} 
Additional & $0.012^{* *}$ & 0.011 & -0.003 & 0.008 & 0.022 \\
woman & $(0.005)$ & $(0.007)$ & $(0.011)$ & $(0.015)$ & $(0.020)$ \\
\hline
\end{tabular}

Panel G. Characteristics of marginal candidates in the previous elections (elections of treatment)

\begin{tabular}{l|l|l|l|l|l|}
\multicolumn{7}{c}{ Length of the marginal winner's slate } \\
Additional & $0.300^{* * *}$ & $0.395^{* * *}$ & $0.340^{*}$ & 0.330 & 0.331 \\
woman & $(0.095)$ & $(0.133)$ & $(0.199)$ & $(0.283)$ & $(0.381)$ \\
Indicator of the marginal winner represents a major party
\end{tabular}

\begin{tabular}{l|l|l|l|l|l} 
Additional & $-0.038^{* * *}$ & -0.016 & -0.021 & 0.016 & -0.013
\end{tabular}




\begin{tabular}{|c|c|c|c|c|c|}
\hline Observations & 5,951 & 4,224 & 2,292 & 1,477 & 925 \\
\hline Sample & ALL & $\begin{array}{l}\text { mandates } \\
<10\end{array}$ & $\begin{array}{l}\text { mandates } \\
<10\end{array}$ & $\begin{array}{l}\text { mandates } \\
<10\end{array}$ & $\begin{array}{l}\text { mandates } \\
<10\end{array}$ \\
\hline $\begin{array}{l}\text { Victory } \\
\text { margin }\end{array}$ & ALL & ALL & {$[-5 ; 5]$} & {$[-2 ; 2]$} & {$[-1 ; 1]$} \\
\hline woman & $(0.014)$ & $(0.013)$ & $(0.021)$ & $(0.030)$ & $(0.039)$ \\
\hline \multicolumn{6}{|c|}{ Median position of women on the marginal winner's slate } \\
\hline Additional & $0.065^{* * *}$ & $0.069^{* * *}$ & 0.028 & 0.032 & 0.025 \\
\hline woman & $(0.009)$ & $(0.012)$ & $(0.020)$ & $(0.028)$ & $(0.036)$ \\
\hline \multicolumn{6}{|c|}{ Share of female candidates on the marginal winner's slate } \\
\hline Additional & $0.399^{* * *}$ & $0.590^{* * *}$ & $0.665^{* *}$ & $0.637^{* * *}$ & $0.631^{* * *}$ \\
\hline woman & $(0.011)$ & $(0.014)$ & $(0.023)$ & $(0.033)$ & $(0.044)$ \\
\hline \multicolumn{6}{|c|}{ Share of female candidates on the marginal loser's slate } \\
\hline Additional & $-0.423^{* * *}$ & $-0.646^{* * *}$ & $-0.730^{* * *}$ & $-0.713^{* * *}$ & $-0.678^{* * *}$ \\
\hline woman & $(0.011)$ & $(0.014)$ & $(0.022)$ & $(0.032)$ & $(0.041)$ \\
\hline \multicolumn{6}{|c|}{ Number of candidates elected from the winner's slate } \\
\hline Additional & 0.148 & $0.283^{* * *}$ & 0.160 & 0.238 & -0.010 \\
\hline woman & $(0.095)$ & $(0.102)$ & $(0.164)$ & $(0.228)$ & $(0.294)$ \\
\hline \multicolumn{6}{|c|}{$\begin{array}{c}\text { Number of female candidates elected from the winner's slate other than the marginally } \\
\text { elected }\end{array}$} \\
\hline Additional & $0.139^{* * *}$ & $0.132^{* * *}$ & 0.006 & 0.045 & 0.046 \\
\hline woman & $(0.039)$ & $(0.043)$ & $(0.063)$ & $(0.084)$ & $(0.102)$ \\
\hline \multicolumn{6}{|c|}{ Age of the marginal winner } \\
\hline Additional & $-1.100^{* *}$ & $-1.138^{*}$ & -0.140 & -0.015 & -1.131 \\
\hline woman & $(0.493)$ & $(0.660)$ & $(1.064)$ & $(1.506)$ & $(1.969)$ \\
\hline \multicolumn{6}{|c|}{ Indicator that the marginal winner has higher education } \\
\hline Additional & $0.031^{*}$ & $0.030^{*}$ & 0.014 & -0.012 & 0.013 \\
\hline woman & $(0.017)$ & $(0.018)$ & $(0.030)$ & $(0.041)$ & $(0.052)$ \\
\hline
\end{tabular}


Table B.7: Co-variate balance check: large municipalities

Model specifications

\begin{tabular}{|l|l|l|l|l|l|}
\hline Observations & $\mathbf{5 , 9 5 1}$ & $\mathbf{1 , 7 2 7}$ & $\mathbf{1 , 4 6 9}$ & $\mathbf{1 , 0 6 3}$ & $\mathbf{7 3 7}$ \\
\hline Sample & ALL & $\begin{array}{l}\text { mandates } \\
>=10\end{array}$ & $\begin{array}{l}\text { mandates } \\
>=10\end{array}$ & $\begin{array}{l}\text { mandates } \\
>=10\end{array}$ & $\begin{array}{l}\text { mandates } \\
>=10\end{array}$ \\
\hline $\begin{array}{l}\text { Victory } \\
\text { margin }\end{array}$ & ALL & ALL & {$[-5 ; 5]$} & {$[-2 ; 2]$} & {$[-1 ; 1]$} \\
\hline
\end{tabular}

Panel A. Demographic indicators

(two-year average - year of elections of treatment and the previous year)

Number of inhabitants

\begin{tabular}{|c|c|c|c|c|c|}
\hline \multirow{3}{*}{$\begin{array}{l}\text { Additional } \\
\text { woman }\end{array}$} & & & & & \\
\hline & 1.966 & 65.877 & 81.513 & 39.564 & -42.741 \\
\hline & (79.383) & $(260.989)$ & $(322.837)$ & $(450.963)$ & $(568.11$ \\
\hline \multicolumn{6}{|c|}{ Number of children born per year } \\
\hline Additional & 0.002 & $\mid 1.287$ & 1.651 & 1.783 & 0.597 \\
\hline woman & $(0.880)$ & $(2.871)$ & $(3.527)$ & $(4.947)$ & $(5.821)$ \\
\hline
\end{tabular}

Panel B. Local budget indicators

(two-year average - year of elections of treatment and the previous year)

Total local budget spending per inhabitant

\begin{tabular}{|c|c|c|c|c|c|}
\hline Additional & 267.212 & 620.238 & -190.020 & -366.512 & 634.418 \\
\hline woman & $(637.118)$ & $(1424.902)$ & $(1705.029)$ & $(2262.720)$ & $(2823.426)$ \\
\hline \multicolumn{6}{|c|}{ Current local budget spending per inhabitant } \\
\hline Additional & 49.786 & 73.247 & -465.576 & 191.677 & 1180.992 \\
\hline woman & $(474.321)$ & $(1277.382)$ & $(1537.343)$ & (2054.664) & $(2518.509)$ \\
\hline \multicolumn{6}{|c|}{ Capital local budget spending per inhabitant } \\
\hline Additional & 217.426 & 546.991 & 275.556 & -558.189 & -546.574 \\
\hline woman & $(353.587)$ & $(507.478)$ & $(592.720)$ & (781.015) & (967.171) \\
\hline \multicolumn{6}{|c|}{ Subsidies received by the municipality per inhabitant } \\
\hline Additional & 393.091 & 587.852 & 30.860 & -50.698 & 1159.752 \\
\hline woman & $(488.861)$ & $(1274.789)$ & $(1529.581)$ & $(2031.736)$ & $(2447.735)$ \\
\hline \multicolumn{6}{|c|}{ Local budget tax income per inhabitant } \\
\hline Additional & 54.241 & 125.755 & 55.861 & -18.965 & -322.976 \\
\hline woman & $(161.190)$ & $(146.491)$ & $(180.673)$ & $(230.002)$ & $(345.975)$ \\
\hline \multicolumn{6}{|c|}{ Local budget non-tax income per inhabitant } \\
\hline Additional & 111.066 & 16.697 & -0.693 & 83.694 & -319.740 \\
\hline woman & $(147.495)$ & $(223.197)$ & $(234.032)$ & $(275.297)$ & $(402.221)$ \\
\hline \multicolumn{6}{|c|}{ Local budget capital income per inhabitant } \\
\hline Additional & $-343.733^{* * *}$ & -156.203 & -206.528 & -136.214 & -222.543 \\
\hline woman & $(120.496)$ & $(153.588)$ & $(193.793)$ & $(318.292)$ & $(464.892)$ \\
\hline
\end{tabular}

Panel C. Share of votes cast to major parties in the previous elections (elections of treatment)

\begin{tabular}{l|l|l|l|l|l} 
Additional & 0.004 & 0.013 & 0.014 & 0.018 & 0.024 \\
woman & $(0.005)$ & $(0.011)$ & $(0.014)$ & $(0.019)$ & $(0.025)$
\end{tabular}

Panel D. Median age of candidates in the previous elections (elections of treatment)

Median age of all candidates (excluding the two marginal)

\begin{tabular}{l|l|l|l|l|l|} 
Additional & 0.256 & 0.359 & 0.243 & 0.189 & 0.891 \\
woman & $(0.230)$ & $(0.327)$ & $(0.385)$ & $(0.545)$ & $(0.760)$ \\
Median age of female candidates (excluding the marginal) \\
Additional & 0.197 & 0.420 & 0.565 & 1.004 & $1.673^{*}$ \\
woman & $(0.451)$ & $(0.434)$ & $(0.501)$ & $(0.710)$ & $(0.934)$
\end{tabular}




\begin{tabular}{|l|l|l|l|l|l|}
\hline Observations & $\mathbf{5 , 9 5 1}$ & $\mathbf{1 , 7 2 7}$ & $\mathbf{1 , 4 6 9}$ & $\mathbf{1 , 0 6 3}$ & $\mathbf{7 3 7}$ \\
\hline Sample & ALL & $\begin{array}{l}\text { mandates } \\
>=10\end{array}$ & $\begin{array}{l}\text { mandates } \\
>=10\end{array}$ & $\begin{array}{l}\text { mandates } \\
>=10\end{array}$ & $\begin{array}{l}\text { mandates } \\
>=10\end{array}$ \\
\hline $\begin{array}{l}\text { Victory } \\
\text { margin }\end{array}$ & ALL & ALL & {$[-5 ; 5]$} & {$[-2 ; 2]$} & {$[-1 ; 1]$} \\
\hline \\
Additional \\
$\begin{array}{l}\text { Median age of elected candidates (excluding the marginal) } \\
\text { woman }\end{array}$ & $\begin{array}{l}0.361 \\
(0.239)\end{array}$ & $\begin{array}{l}0.419 \\
(0.325)\end{array}$ & $\begin{array}{l}0.413 \\
(0.384)\end{array}$ & $\begin{array}{l}0.420 \\
(0.538)\end{array}$ & $\begin{array}{l}0.515 \\
(0.723)\end{array}$
\end{tabular}

Median age of elected female candidates (excluding the marginal)

\begin{tabular}{l|l|l|l|l|l} 
Additional & $1.206^{*}$ & 0.859 & 1.550 & 1.288 & 0.252 \\
woman & $(0.677)$ & $(0.856)$ & $(1.050)$ & $(1.454)$ & $(1.909)$
\end{tabular}

Panel E. Share of educated candidates in the previous elections (elections of treatment)

Share of educated candidates among all candidates (excluding the two marginal)

\begin{tabular}{l|l|l|l|l|l} 
Additional & $0.031^{*}$ & 0.006 & -0.011 & -0.054 & 0.052 \\
woman & $(0.017)$ & $(0.039)$ & $(0.047)$ & $(0.066)$ & $(0.088)$
\end{tabular}

Share of educated female candidates among all female candidates (excluding the

\begin{tabular}{l|l|l|l|l|l|}
\multicolumn{5}{|c}{ marginal) } \\
Additional & 0.010 & 0.002 & -0.002 & -0.011 & -0.005 \\
woman & $(0.008)$ & $(0.011)$ & $(0.013)$ & $(0.017)$ & $(0.023)$
\end{tabular}

Share of educated candidates among elected candidates (excluding the marginal)

\begin{tabular}{l|l|l|l|l|l} 
Additional & $0.017^{* *}$ & 0.013 & 0.005 & 0.012 & 0.046 \\
woman & $(0.008)$ & $(0.014)$ & $(0.017)$ & $(0.024)$ & $(0.032)$
\end{tabular}

Share of educated female candidates among elected female candidates (excluding the

\begin{tabular}{l|l|l|l|l|l}
\multicolumn{5}{|c}{ marginal } \\
Additional & 0.018 & -0.006 & -0.013 & -0.044 & -0.019 \\
woman & $(0.013)$ & $(0.026)$ & $(0.031)$ & $(0.042)$ & $(0.055)$
\end{tabular}

Panel F. Female political participation in the previous elections (elections of treatment)

\begin{tabular}{|c|c|c|c|c|c|}
\hline \multicolumn{6}{|c|}{ Number of female candidates } \\
\hline Additional & $0.667^{*}$ & $1.697^{*}$ & 1.870 & $2.868^{*}$ & 1.339 \\
\hline woman & $(0.357)$ & $(0.993)$ & $(1.223)$ & $(1.666)$ & $(2.260)$ \\
\hline \multicolumn{6}{|c|}{ Share of female candidates } \\
\hline Additional & 0.004 & 0.010 & $0.014^{*}$ & 0.010 & 0.000 \\
\hline woman & $(0.005)$ & $(0.006)$ & $(0.007)$ & $(0.010)$ & $(0.013)$ \\
\hline
\end{tabular}

\begin{tabular}{l|l|l|l|l|l}
\multicolumn{7}{c}{ Number of elected female candidates (excluding the marginal) } \\
Additional & 0.079 & 0.028 & 0.161 & -0.163 & -0.246 \\
woman & $(0.060)$ & $(0.145)$ & $(0.176)$ & $(0.241)$ & $(0.314)$
\end{tabular}

Median position of female candidates on slates

\begin{tabular}{l|l|l|l|l|l} 
Additional & -0.003 & 0.006 & 0.017 & 0.014 & 0.017 \\
woman & $(0.007)$ & $(0.010)$ & $(0.013)$ & $(0.019)$ & $(0.026)$
\end{tabular}

\begin{tabular}{l|l|l|l|l|l|}
\multicolumn{7}{c}{ Share of votes cast to female candidates in the municipality } \\
Additional & $0.012^{* *}$ & $0.011^{*}$ & $0.016^{* *}$ & 0.009 & -0.001 \\
woman & $(0.005)$ & $(0.006)$ & $(0.008)$ & $(0.010)$ & $(0.014)$
\end{tabular}

Panel G. Characteristics of marginal candidates in the previous elections (elections of treatment)

Length of the marginal winner's slate

\begin{tabular}{l|l|l|l|l|l} 
Additional & $0.221^{*}$ & 0.214 & 0.239 & 0.355 & 0.488 \\
woman & $(0.122)$ & $(0.215)$ & $(0.277)$ & $(0.435)$ & $(0.641)$ \\
Additional & $-0.038^{* * *}$ & -0.040 & -0.057 & -0.062 & -0.102
\end{tabular}




\begin{tabular}{|c|c|c|c|c|c|}
\hline Observations & 5,951 & 1,727 & 1,469 & 1,063 & 737 \\
\hline Sample & ALL & $\begin{array}{l}\text { mandates } \\
>=10\end{array}$ & $\begin{array}{l}\text { mandates } \\
>=10\end{array}$ & $\begin{array}{l}\text { mandates } \\
>=10\end{array}$ & $\begin{array}{l}\text { mandates } \\
>=10\end{array}$ \\
\hline $\begin{array}{l}\text { Victory } \\
\text { margin }\end{array}$ & ALL & ALL & {$[-5 ; 5]$} & {$[-2 ; 2]$} & {$[-1 ; 1]$} \\
\hline woman & $(0.014)$ & $(0.034)$ & $(0.041)$ & $(0.056)$ & $(0.074)$ \\
\hline \multicolumn{6}{|c|}{ Median position of women on the marginal winner's slate } \\
\hline Additional & $0.065^{* * *}$ & $0.062^{* * *}$ & $0.069^{* * *}$ & $0.076^{* * *}$ & $0.105^{* * *}$ \\
\hline woman & $(0.009)$ & $(0.014)$ & $(0.017)$ & $(0.024)$ & $(0.033)$ \\
\hline \multicolumn{6}{|c|}{ Share of female candidates on the marginal winner's slate } \\
\hline Additional & $0.399^{* * *}$ & $0.136^{* * *}$ & $0.144^{* * *}$ & $0.162^{* * *}$ & $0.144^{* * *}$ \\
\hline woman & $(0.011)$ & $(0.014)$ & $(0.018)$ & $(0.025)$ & $(0.035)$ \\
\hline \multicolumn{6}{|c|}{ Share of female candidates on the marginal loser's slate } \\
\hline Additional & $-0.423^{* * *}$ & $-0.134^{* * *}$ & $-0.130^{* * *}$ & $-0.142^{* * *}$ & $-0.149^{* * *}$ \\
\hline woman & $(0.011)$ & $(0.015)$ & $(0.019)$ & $(0.027)$ & $(0.039)$ \\
\hline \multicolumn{6}{|c|}{ Number of candidates elected from the winner's slate } \\
\hline Additional & 0.148 & 0.003 & -0.060 & -0.570 & -0.131 \\
\hline woman & $(0.095)$ & $(0.219)$ & $(0.258)$ & $(0.355)$ & $(0.461)$ \\
\hline \multicolumn{6}{|c|}{$\begin{array}{l}\text { Number of female candidates elected from the winner's slate other than the marginall } \\
\text { elected }\end{array}$} \\
\hline Additional & $0.139^{* * *}$ & 0.106 & 0.133 & -0.007 & 0.042 \\
\hline woman & $(0.039)$ & $(0.086)$ & $(0.100)$ & $(0.135)$ & $(0.179)$ \\
\hline \multicolumn{6}{|c|}{ Age of the marginal winner } \\
\hline Additional & $-1.100^{* *}$ & -0.770 & -1.395 & 0.309 & 0.834 \\
\hline woman & $(0.493)$ & $(0.880)$ & $(1.054)$ & $(1.479)$ & $(1.974)$ \\
\hline \multicolumn{6}{|c|}{ Indicator that the marginal winner has higher education } \\
\hline Additional & -0.004 & -0.041 & -0.031 & -0.091 & -0.132 \\
\hline woman & $(0.017)$ & $(0.039)$ & $(0.047)$ & $(0.065)$ & $(0.086)$ \\
\hline
\end{tabular}


Table B.8: Main results: large municipalities

Model specifications

\begin{tabular}{|l|l|l|l|l|l|}
\hline Observations & $\mathbf{6 , 0 8 8}$ & $\mathbf{1 , 8 3 2}$ & $\mathbf{1 , 5 7 0}$ & $\mathbf{1 , 1 4 9}$ & $\mathbf{8 0 5}$ \\
\hline Sample & ALL & mandates $>=10$ & mandates $>=10$ & mandates $>=10$ & mandates $>=10$ \\
\hline $\begin{array}{l}\text { Victory } \\
\text { margin }\end{array}$ & ALL & ALL & {$[-5 ; 5]$} & {$[-2 ; 2]$} & {$[-1 ; 1]$} \\
\hline
\end{tabular}

Panel A

Number of female candidates

\begin{tabular}{l|l|l|l|l|l} 
Additional & 0.622 & 1.332 & 1.904 & 3.097 & 2.934 \\
woman & $(0.407)$ & $(1.168)$ & $(1.454)$ & $(1.949)$ & $(2.516)$ \\
Adj. R-sq & 0.827 & 0.790 & 0.789 & 0.808 & 0.805 \\
\hline
\end{tabular}

Number of female candidates, excluding the marginally winning or losing female candidates

\begin{tabular}{l|l|l|l|l|l} 
Additional & 0.471 & 1.257 & 1.820 & 2.983 & 2.802 \\
woman & $(0.406)$ & $(1.167)$ & $(1.452)$ & $(1.947)$ & $(2.514)$ \\
Adj. R-sq & 0.827 & 0.791 & 0.790 & 0.808 & 0.805 \\
\hline
\end{tabular}

Participation probability: marginal female winner vs loser

\begin{tabular}{l|l|l|l|l|l} 
Additional & $0.151^{* * *}$ & $0.075^{*}$ & $0.085^{*}$ & $0.114^{*}$ & $0.131^{+}$ \\
woman & $(0.021)$ & $(0.041)$ & $(0.049)$ & $(0.066)$ & $(0.088)$ \\
Adj. R-sq & 0.047 & 0.014 & 0.007 & 0.017 & 0.026 \\
\hline
\end{tabular}

Panel D

Probability to win again conditional on participating again: marginal female winner vs loser

\begin{tabular}{|l|l|l|l|l|l|}
\hline Observations & $\mathbf{3 , 1 7 2}$ & $\mathbf{1 , 1 0 7}$ & $\mathbf{9 4 8}$ & $\mathbf{7 0 7}$ & $\mathbf{4 9 4}$ \\
\hline Additional & $0.149^{* * *}$ & $0.110^{* *}$ & 0.070 & 0.028 & 0.058 \\
woman & $(0.030)$ & $(0.055)$ & $(0.064)$ & $(0.089)$ & $(0.120)$ \\
Adj. R-sq & 0.048 & 0.010 & 0.013 & 0.018 & 0.014 \\
\hline
\end{tabular}

Panel E

Number of newly participating female candidates

\begin{tabular}{l|l|l|l|l|l} 
Additional & 0.200 & 0.596 & 1.033 & 1.883 & 2.036 \\
woman & $(0.307)$ & $(0.895)$ & $(1.117)$ & $(1.500)$ & $(1.909)$ \\
Adj. R-sq & 0.803 & 0.782 & 0.783 & 0.804 & 0.797
\end{tabular}

Note: Elections year*council size fixed effects and robust standard errors used in all regressions.

${ }^{+} P$-value $=0.135$. Quadratic victory margin controlled for in all regressions. 
Table B.9: Robustness checks

Model specifications

\begin{tabular}{l|l|l|l|l|l|}
\hline Sample & ALL & $\begin{array}{l}\text { mandates } \\
<\mathbf{1 0}\end{array}$ & $\begin{array}{l}\text { mandates } \\
<\mathbf{1 0}\end{array}$ & $\begin{array}{l}\text { mandates } \\
<\mathbf{1 0}\end{array}$ & $\begin{array}{l}\text { mandates } \\
<\mathbf{1 0}\end{array}$ \\
\hline $\begin{array}{l}\text { Victory } \\
\text { margin }\end{array}$ & ALL & ALL & {$[-5 ; 5]$} & {$[-2 ; 2]$} & {$[-1 ; 1]$} \\
\hline $\begin{array}{l}\text { Panel A } \\
\text { Number of newly participating female candidates - excluding high jumpers and party }\end{array}$ \\
\begin{tabular}{|l|l|l|l|l|} 
favourites from the sample \\
Observations
\end{tabular} & $\mathbf{3 1 8 2}$ & $\mathbf{2 5 5 0}$ & $\mathbf{1 5 3 1}$ & $\mathbf{1 0 6 2}$ & $\mathbf{7 0 3}$ \\
\hline Additional & 0.208 & 0.242 & -0.263 & -0.368 & $-0.809^{*}$ \\
woman & $(0.338)$ & $(0.193)$ & $(0.304)$ & $(0.395)$ & $(0.460)$ \\
\hline
\end{tabular}

Panel B

Number of newly participating female candidates - excluding high jumpers and party favourites from the sample -

municipalities with 2 or more non-marginal female candidates elected

\begin{tabular}{|l|l|l|l|l|l|}
\hline Observations & $\mathbf{1 8 5 6}$ & $\mathbf{1 3 1 2}$ & $\mathbf{7 8 8}$ & $\mathbf{5 5 4}$ & $\mathbf{3 6 9}$ \\
\hline Additional & -0.006 & 0.139 & $-0.950^{* *}$ & $-0.960^{+}$ & $-1.613^{* *}$ \\
woman & $(0.524)$ & $(0.296)$ & $(0.473)$ & $(0.625)$ & $(0.769)$ \\
\hline
\end{tabular}

Panel C

Number of newly participating female candidates - excluding high jumpers and party favourites from the sample -

municipalities with none or 1 non-marginal female candidates elected

\begin{tabular}{|l|l|l|l|l|l|}
\hline Observations & $\mathbf{1 3 2 6}$ & $\mathbf{1 2 3 8}$ & $\mathbf{7 4 3}$ & $\mathbf{5 0 8}$ & $\mathbf{3 3 4}$ \\
\hline Additional & 0.493 & 0.386 & 0.442 & 0.186 & -0.182 \\
woman & $(0.305)$ & $(0.243)$ & $(0.378)$ & $(0.484)$ & $(0.556)$ \\
\hline
\end{tabular}

Panel D
Number of newly participating female candidates

\begin{tabular}{|l|l|l|l|l|l|}
\hline Observations & $\mathbf{6 , 0 8 8}$ & $\mathbf{4 , 2 5 6}$ & $\mathbf{2 , 3 1 4}$ & $\mathbf{1 , 4 8 9}$ & $\mathbf{9 3 5}$ \\
\hline Additional & 0.085 & 0.043 & $-0.468^{*}$ & -0.479 & $-1.197^{* * *}$ \\
woman & $(0.299)$ & $(0.173)$ & $(0.282)$ & $(0.378)$ & $(0.450)$ \\
High jumper & 0.476 & -0.092 & -0.392 & $-1.056^{*}$ & -0.789 \\
*Add.wom. & $(0.516)$ & $(0.354)$ & $(0.489)$ & $(0.586)$ & $(0.784)$ \\
\hline
\end{tabular}

Panel E

Number of newly participating female candidates - excluding high jumpers from the sample

\begin{tabular}{|l|l|l|l|l|l|}
\hline Observations & $\mathbf{5 , 1 7 2}$ & $\mathbf{3 , 3 3 2}$ & $\mathbf{2 , 0 4 5}$ & $\mathbf{1 , 3 3 6}$ & $\mathbf{8 4 6}$ \\
\hline Additional & -0.011 & -0.038 & $-0.449^{++}$ & -0.338 & $-0.777^{*}$ \\
woman & $(0.305)$ & $(0.395)$ & $(0.288)$ & $(0.378)$ & $(0.443)$
\end{tabular}

Note: Elections year ${ }^{*}$ council size fixed effects and robust standard errors used in all regressions. ${ }^{+} P$-value $=0.125 .{ }^{++} P$ value $=0.119$. Quadratic victory margin is controlled for in all regressions, as well as the main effect of the marginally elected candidate being a high jumper in regressions in Panel D. 
Table B.10: Does partisanship matter?

Model specifications

\begin{tabular}{l|l|l|l|l|l|}
\hline Sample & ALL & mandates $<\mathbf{1 0}$ & mandates $<10$ & mandates $<10$ & mandates $<10$ \\
\hline $\begin{array}{l}\text { Victory } \\
\text { margin }\end{array}$ & ALL & ALL & {$[-5 ; 5]$} & {$[-2 ; 2]$} & {$[-1 ; 1]$} \\
\hline \multicolumn{5}{|c|}{ Panel A - Number of newly participating female candidates } \\
\hline Observations & 6,088 & 4,256 & 2,314 & 1,489 & 935 \\
\hline Additional & 0.290 & 0.075 & $-0.510^{*}$ & -0.608 & $-1.265^{* * *}$ \\
woman & $(0.301)$ & $(0.172)$ & $(0.282)$ & $(0.379)$ & $(0.469)$ \\
Winner from & -0.342 & -0.562 & -0.881 & -1.041 & -0.275 \\
major party & $(0.699)$ & $(0.478)$ & $(0.675)$ & $(0.989)$ & $(1.438)$ \\
*Add.wom. & & & & & \\
\hline
\end{tabular}

Panel B - Number of newly participating female candidates - excluding major party representatives from the sample

\begin{tabular}{|c|c|c|c|c|c|}
\hline Observations & 5,441 & 3,414 & 2,166 & 1,404 & 889 \\
\hline Additional & 0.438 & 0.169 & $-0.512^{*}$ & -0.421 & $-0.942^{* *}$ \\
\hline woman & $(0.300)$ & $(0.381)$ & $(0.282)$ & $(0.378)$ & $(0.465)$ \\
\hline \multicolumn{6}{|c|}{ Panel C - Number of newly participating female candidates } \\
\hline Observations & 6,088 & 4,256 & 2,314 & 1,489 & 935 \\
\hline Additional & 0.150 & -0.048 & $-0.544^{* *}$ & $-0.687^{*}$ & $-1.223^{* * *}$ \\
\hline woman & $(0.304)$ & $(0.166)$ & $(0.272)$ & $(0.366)$ & $(0.441)$ \\
\hline Individual & $-573^{* * *}$ & $-1.993^{* * *}$ & $-2.095^{* * *}$ & $-2.143^{* * *}$ & $-2.213^{* * *}$ \\
\hline candidate & $(0.135)$ & $(0.119)$ & $(0.128)$ & $(0.153)$ & $(0.187)$ \\
\hline \multicolumn{6}{|c|}{ Panel D - Number of newly participating female candidates } \\
\hline Observations & 6,088 & 4,256 & 2,314 & 1,489 & 935 \\
\hline Additional & 0.115 & -0.254 & $-0.972^{* * *}$ & $-1.261^{* * *}$ & $-1.816^{* * *}$ \\
\hline woman & $(0.387)$ & $(0.247)$ & $(0.351)$ & $(0.438)$ & $(0.528)$ \\
\hline Individual & $-626^{* * *}$ & $-2.186^{* * *}$ & $-2.424^{* * *}$ & $-2.630^{* * *}$ & $-2.733^{* * *}$ \\
\hline candidate & $(0.207)$ & $(0.165)$ & $(0.175)$ & $(0.215)$ & $(0.280)$ \\
\hline Individual & 0.116 & $0.419^{*}$ & $0.723^{* * *}$ & $1.027^{* * *}$ & $1.090^{* * *}$ \\
\hline candidate & $(0.325)$ & $(0.232)$ & $(0.249)$ & $(0.305)$ & $(0.390)$ \\
\hline *Add.wom. & & & & & \\
\hline \multicolumn{6}{|c|}{$\begin{array}{c}\text { Panel E - Number of newly participating female candidates - municipalities where the } \\
\text { marginally elected was an individual candidate }\end{array}$} \\
\hline Observations & 917 & 882 & 831 & 680 & 485 \\
\hline Additional & 0.268 & 0.271 & 0.144 & -0.098 & -0.140 \\
\hline woman & $(0.196)$ & $(0.184)$ & $(0.234)$ & $(0.312)$ & $(0.377)$ \\
\hline
\end{tabular}

Panel F - Number of newly participating female candidates - excluding marginally elected individual candidates

\begin{tabular}{|l|l|l|l|l|l|}
\hline Observations & 5,171 & 3,374 & 1,483 & 809 & 450 \\
\hline Additional & 0.061 & -0.366 & $-1.361^{* * *}$ & $-1.362^{* *}$ & $-2.641^{* * *}$ \\
woman & $(0.404)$ & $(0.263)$ & $(0.480)$ & $(0.686)$ & $(0.882)$
\end{tabular}

Note: Elections year* council size fixed effects and robust standard errors used in all regressions. Quadratic victory margin is controlled for in all regressions, as well as the main effect of the marginally elected candidate representing a major party in regressions in Panel $A$. 
Table B.11: Long-term effect: Trend in coefficient Model specifications - small municipalities

\begin{tabular}{|c|c|c|c|c|c|}
\hline Observations & 3,760 & 2,620 & 1,453 & 941 & 588 \\
\hline Sample & ALL & $\begin{array}{l}\text { mandates } \\
<10\end{array}$ & $\begin{array}{l}\text { mandates } \\
<10\end{array}$ & $\begin{array}{l}\text { mandates } \\
<10\end{array}$ & $\begin{array}{l}\text { mandates } \\
<10\end{array}$ \\
\hline $\begin{array}{l}\text { Victory } \\
\text { margin }\end{array}$ & ALL & ALL & {$[-5 ; 5]$} & {$[-2 ; 2]$} & {$[-1 ; 1]$} \\
\hline \multicolumn{6}{|c|}{ Panel A Number of female candidates } \\
\hline Additional & $1.227^{* *}$ & 0.348 & 0.469 & 0.436 & 0.122 \\
\hline woman & $(0.537)$ & $(0.319)$ & $(0.533)$ & $(0.748)$ & $(0.973)$ \\
\hline
\end{tabular}

Panel B - Number of female candidates, excluding the marginally winning or losing female candidates

\begin{tabular}{l|l|l|l|l|l} 
Additional & 0.580 & -0.254 & -0.122 & -0.119 & -0.404 \\
woman & $(0.537)$ & $(0.320)$ & $(0.535)$ & $(0.752)$ & $(0.977)$
\end{tabular}

Panel C - Number of newly participating female candidates

\begin{tabular}{|c|c|c|c|c|c|}
\hline Additional & $0.804^{* *}$ & 0.289 & 0.352 & 0.119 & -0.318 \\
\hline woman & $(0.409)$ & $(0.243)$ & $(0.410)$ & $(0.578)$ & $(0.753)$ \\
\hline \multicolumn{6}{|c|}{ Panel D - Number of female candidates } \\
\hline Additional & & 2.264 & 3.101 & 5.146 & 5.415 \\
\hline woman & & $(1.550)$ & (1.919) & $(2.730)$ & $(3.627)$ \\
\hline
\end{tabular}

Panel E - Number of female candidates, excluding the marginally winning or losing female candidates

\begin{tabular}{l|l|l|l|l|l|} 
Additional & 1.557 & 2.379 & 4.389 & 4.675 \\
woman & $(1.551)$ & $(1.921)$ & $(2.737)$ & $(3.639)$ \\
\hline
\end{tabular}

Panel F - Number of newly participating female candidates

\begin{tabular}{l|l|l|l|l|l} 
Additional & 1.316 & 1.967 & 2.895 & 3.275 \\
woman & $(1.197)$ & $(1.483)$ & $(2.095)$ & $(2.799)$
\end{tabular}

Note: Elections year* council size fixed effects, quadratic victory margin and robust standard errors used in all regressions. 